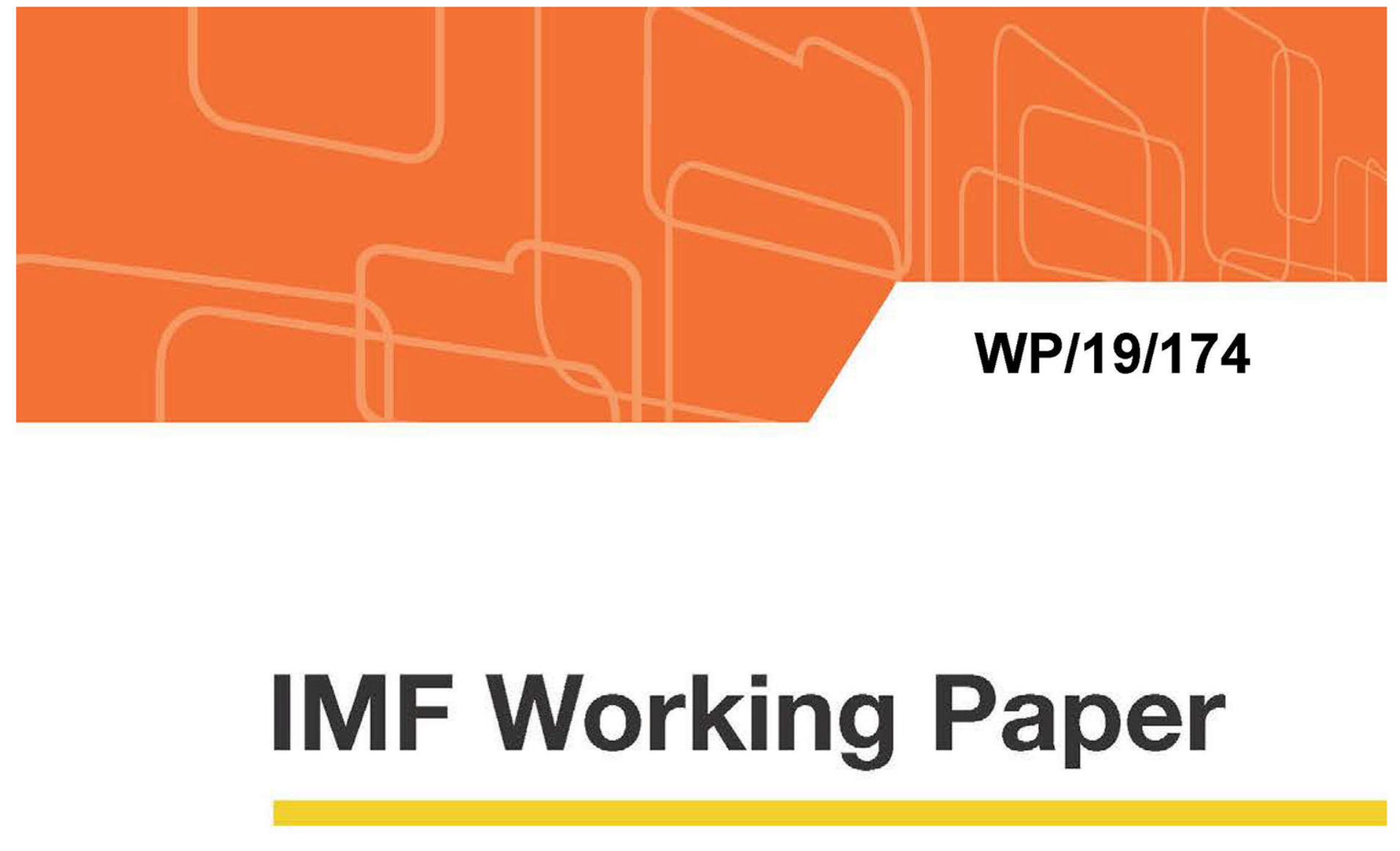

\title{
Gender Equality and Electoral Violence in Africa: Unlocking the Peacemaking Potential of Women
}

by Rasmane Ouedraogo and Idrissa Ouedraogo

IMF Working Papers describe research in progress by the author(s) and are published to elicit comments and to encourage debate. The views expressed in IMF Working Papers are those of the author(s) and do not necessarily represent the views of the IMF, its Executive Board, or IMF management.

$$
\text { I N T ER N A T I O N A L M O N E T A R Y F U N D }
$$




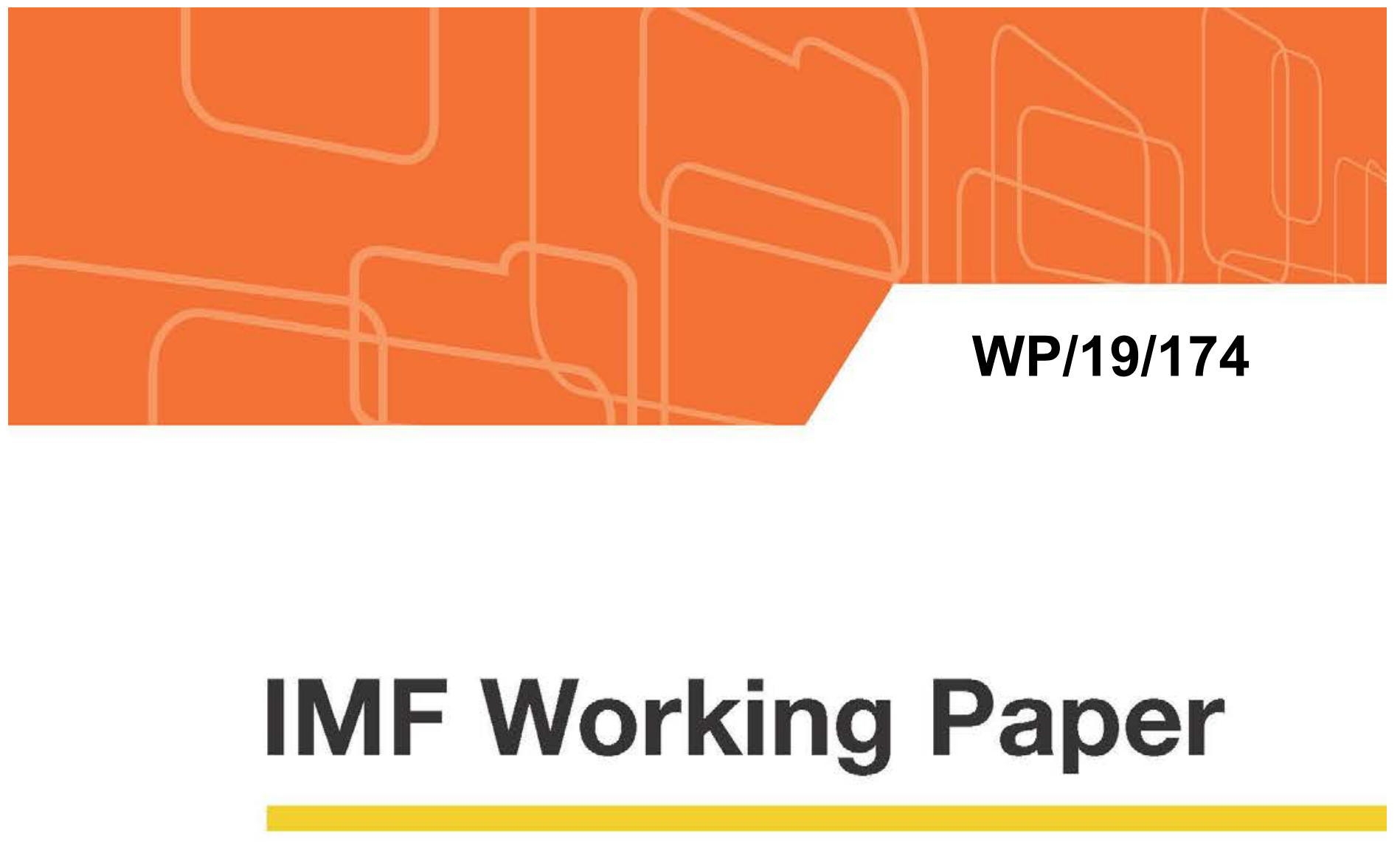

\section{Gender Equality and Electoral Violence in Africa: Unlocking the Peacemaking Potential of Women}

by Rasmane Ouedraogo and Idrissa Ouedraogo

IMF Working Papers describe research in progress by the author(s) and are published to elicit comments and to encourage debate. The views expressed in IMF Working Papers are those of the author(s) and do not necessarily represent the views of the IMF, its Executive Board, or IMF management.

$$
\text { I N T ER N A T I O N A L M O NETAR Y FU N D }
$$




\title{
IMF Working Paper
}

\author{
African Department \\ Gender Equality and Electoral Violence in Africa: \\ Unlocking the Peacemaking Potential of Women \\ Prepared by Rasmane Ouedraogo and Idrissa Ouedraogo ${ }^{1}$ \\ Authorized for distribution by Axel Schimmelpfennig
}

July 2019

\begin{abstract}
IMF Working Papers describe research in progress by the author(s) and are published to elicit comments and to encourage debate. The views expressed in IMF Working Papers are those of the author(s) and do not necessarily represent the views of the IMF, its Executive Board, or IMF management.
\end{abstract}

We examine the impact of gender equality on electoral violence in Africa using micro-level data from the sixth round of Afrobarometer surveys. The sample covers 30 countries. We find that gender equality is associated with lower electoral violence. Quantitatively, our estimates show that an increase in female-to-male labor force participation ratio by 1 percentage point is correlated with a reduction of the probability of electoral violence across the continent by around 4.2 percentage points. Our results are robust to alternative ways to measure electoral violence and gender equality, as well as to alternative specifications. The findings of this paper support the long-standing view that women empowerment contributes to the reduction of violence and underscore the urgency of addressing gender inequality in Africa.

JEL Classification Numbers: D72, D74, J16, O55

Keywords: gender equality, electoral violence, Africa

Author's E-Mail Address: rouedraogo@imf.org; idriss_mo@yahoo.fr

\footnotetext{
${ }^{1}$ The authors would like to thank Axel Schimmelpfennig, Mahvash Saeed Qureshi, Monique Newiak, Emre Alper, Claudia Berg, Suhaib Kebhaj, Grace Li, and participants at the AFR Inclusive Growth Seminar Series for helpful discussions and comments. Idrissa Ouedraogo is Professor at University Ouaga II (Burkina Faso).
} 


\section{Contents}

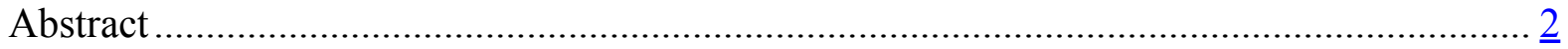

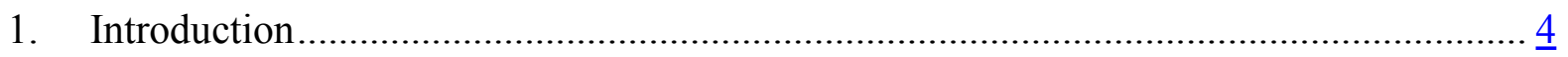

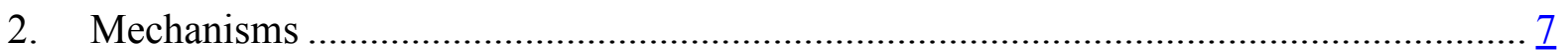

3. Data sources and descriptive statistics ............................................................. 11

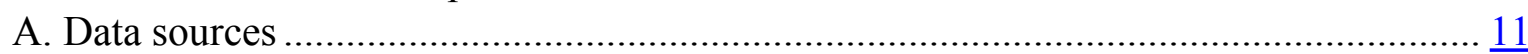

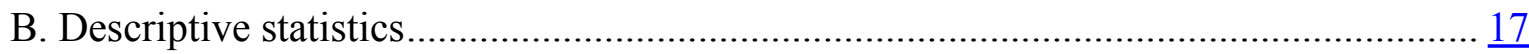

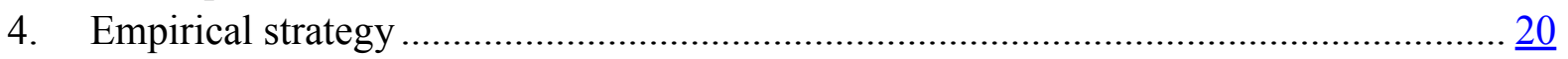

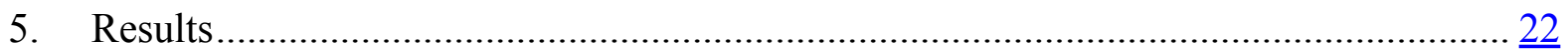

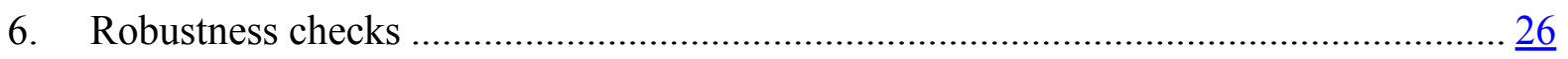

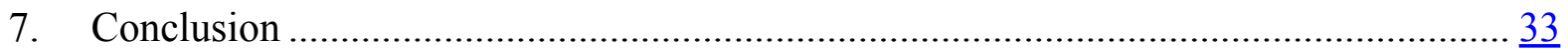

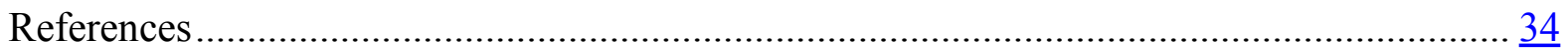

\section{Tables}

Table 1: Descriptive statistics ............................................................................. $\frac{18}{24}$

Table 2: Baseline results ....................................................................................... $\frac{24}{24}$

Table 3: Robustness check: using alternative definition of electoral violence .................... $\frac{27}{28}$

Table 4: Robustness check: using alternative definition of gender equality ....................... $\underline{28}$

Table 5: Robustness check: including additional variables ....................................... $\underline{30}$

Table 6: Robustness check: exclusion of countries of the sample ................................... $\underline{32}$

\section{Figures}

Figure 1: Gender equality and electoral violence per country (average values).....

Figure 2: Relationship between female-to-male labor force participation ratio and growth in rainfall 


\section{INTRODUCTION}

"If non-violence is the Law of our being, the future is with Women. Who can make a more effective appeal to the heart than woman?" (Mahatma Gandhi in 'To the Women of India, Oct. 4, 1930)')

Although elections constitute one of the most important pillars of democracy, they are in most African countries characterized by uncertainties due to the high possibility of electionrelated violence. During elections, the stability and security of African states hang in the balance. Electoral violence is a major problem on the continent and threatens the development and consolidation of democracy. According to Buchard (2015), while there has been a substantial year-to-year variation in the frequency of election-related violence in recent years, around 50 percent of elections are still subject to violence. Violence in Côte d'Ivoire following the 2010 presidential election may have displaced as many as one million and caused more than 3000 deaths; the Kenyan 2007/2008 post-election turmoil killed 1,300 people and displaced some 350,000; in Nigeria more than 1,000 people died over the 2011 polls (Atwood, 2012). The 2017 Kenya presidential election was again subject of violence and destruction, resulting in the deaths of dozens of people.

Yet, no study is known to have investigated the empirical impact of gender equality on electoral violence. Electoral violence is carried out in order to determine, delay, or to otherwise influence an electoral process (Fischer, 2002) and can happen before, during or after an election. There is a fast-growing literature on electoral violence in Africa (Sterck 2017; Colombo et al. 2017; Goldsmith 2014; Collier and Vicente 2013; Collier and Vicente 2012; Dercon and Gutierrez-Romero 2012; Dupas and Robinson 2010, 2012; Blattman 2009; Suberu, 2007; Klopp and Kamungi 2007). Several theories have been postulated to explain electoral violence in Africa, including ethnic and political cleavages (Colombo et al. 2017; Eifert et al. 2010; Wilkinson, 2004), natural resources (Collier et al. 2008), political competition (Sterck, 2017; Collier and Vicente, 2012; Robinson and Torvik 2009), weak governance (Gutiérrez-Romero, 2014; Omotola 2010; Collier et al. 2008) and fragility and past conflicts (Collier and Vicente 2012, Brancati and Snyder 2012). None of these studies empirically explored the impact of gender equality on electoral violence while it has been widely shared in the literature that closing the gender gap is correlated with a reduction in 
conflict occurrence (Demeritt et al. 2014; Melander 2005a, 2016; Caprioli 2000, 2005). Existing literature associates women with an aversion to violence and an inclination toward peace and argues that including women in society makes violent conflict less likely (Demeritt et al. 2014). Countries with greater gender equality and female participation tend to adopt more generally peaceful preferences, leading to a reduced likelihood of political violence (Goldstein 2001). This echoes Mahatma Gandhi's statement above. At the same time, some authors argue that women may also act as perpetrators of violence (Ortbals and PoloniStaudinger, 2018; Bardall, 2011).

The present paper investigates the impact of gender equality on electoral violence in Africa using micro-level data from the sixth wave of Afrobarometer surveys. We estimate the effect of female labor force participation on the perception of electoral violence and control for several covariates. The most obvious issue that we have is an endogeneity problem. Endogeneity may emerge as a result of reverse causality, measurement errors, omitted variables or unobservable factors that cannot be controlled or accounted for. One may argue that electoral violence can in turn affect female labor force participation, thus creating a reverse causality issue. To overcome this endogeneity problem, we employ an instrument variable approach in which we instrument the female-to-male labor force participation ratio with rainfall growth. Rainfall growth is positively associated with female labor force participation owing to jobs opportunities for women in the agriculture sector. According to Jayne, Yeboah and Henry (2017), the agriculture sector remains the single largest source of employment in Africa, and women make up almost 50 percent of the agriculture labor force in the continent (FAO, 2011). However, as Miguel et al (2004) argued, shocks in rainfall can generate economic fluctuations and lead to conflict in Africa as the continent is still reliant on rain-fed agriculture but that may not be the case in other regions of the world. Thus, we acknowledge that there are several alternative causal paths, aside from the labor market mechanism, through which shock in rainfall could also lead to civil violence. Although we tried to control for the alternative channels, we remain cautious that that our results may not fully imply causation and are therefore interpreted as correlations.

The empirical analysis is based on the combination of two main data sets. First, we use Afrobarometer surveys' detailed data on more than 40,000 individuals from 30 African 
countries. These data contain information on the respondents' geographical areas but also the responses of individuals on their own experience or perception of election related violence, and the participation of women in the labor market. Second, we geographically match the 40808 respondents' administrative regions from Afrobarometer Surveys with data on rainfalls from Ben Yishay et al (2017).

We find that gender equality is associated with a reduction in electoral violence. The findings are robust to several robustness checks including using alternative definition of electoral violence, alternative gender equality variable, inclusion of more covariates, and different sample of countries. The paper underscores the importance of achieving gender equality and women empowerment in Africa. Our results provide a novel contribution to the longstanding debate about the role of gender inequality as a determinant of civil conflicts.

Our paper contributes to the literature in two ways. First, to the best of our knowledge we are the first ones to explore the impact of gender equality on electoral violence in Africa. While previous literature has widely studied the impact of gender equality on conflicts, our paper is the first to specifically focus on electoral violence.

Second, we use micro-level data which have several advantages compared to macro-level data used in many papers. While macro-level data on electoral violence rely on physical and observable signs of occurrence of events including killings and demonstrations, survey data allow us to capture each respondent's experienced or perceived level of violence along with characteristics of the individual (Wallsworth 2015). It is worth noting that not all violence can be captured in event data. Thus, political intimidation, blackmail, coercion, threat, psychological manipulation, and verbal abuse are generally excluded from macro-level events of measurement of electoral violence, while they are all some forms of electoral violence. The macro-event data rely only on physical acts of violence that take place in the public sphere. Moreover, macro-level events of electoral violence aggregate the number of events that happens during an election and allocate that number to the whole country despite the fact that the events may occur only in some specific zones. Given this possible withincountry heterogeneity, aggregating information into a country level may lead to misleading 
conclusions. Another drawback of macro data is that electoral violence that happen in remote areas, with limited media coverage, are often not reported.

The paper is organized as follows. Section 2 discusses the mechanisms through which gender inequality affects conflicts. Section 3 presents the data and some descriptive statistics. Section 4 describes the empirical strategy, while Section 5 reports and analyzes the results. Section 6 discusses a range of robustness checks. Section 7 concludes.

\section{MeChANiSMS}

In this section, we describe the mechanisms through which gender equality can affect electoral violence. We first focus on the potential negative effect of gender equality on violence.

\section{Structural violence}

This concept coined by Galtung (1969) refers to a form of violence wherein some social structure or social institution may harm people by preventing them from meeting their basic needs. According to this approach, gendered structural hierarchies, which are maintained by norms of violence and oppression, should result in higher levels of intrastate violence by inuring people to violence and by providing the framework for justifying violence (UNESCO 1995).

Structural violence is often aimed at women, and is maintained through gender socialization, gender stereotyping and a constant threat of violence, all of which insidiously identify women as inferior, influencing their actions at all levels (Caprioli, 2005; Bunch and Carrillo, 1998). Structural violence is expressed in unemployment, unequal access to goods and services, and exploitation. It involves more mediated and multi-factor forms of oppression in which sexism, and other forms of social pathology frequently come together with economic exploitation and deprivation. Winter and Leighton (2001) argued that structural violence is 
the violence of injustice and inequity_ “embedded in ubiquitous social structures [and] normalized by stable institutions and regular experience" (Winter and Leighton, 2001:99). Thus, structural violence is also one way of describing social arrangements that put individuals and populations in harm's way. The arrangements are structural because they are embedded in the political and economic organization of our social world; they are violent because they cause injury to people (Farmer 2010). Galtung (1975) identified four components of structural violence, namely (i) exploitation which is focused on the division of labor with the benefits being asymmetrically distributed, (ii) penetration which necessitates the control by the exploiters over the consciousness of the exploited thus resulting in the acquiescence of the oppressed, (iii) fragmentation which means that the exploited are separated from each other, and (iv) marginalization with the exploiters as a privileged class with their own rules and form of interaction (Caprioli, 2005). The third component refers, for instance, to the exclusion of women from the labor market, which is the subject of this study. It results from women having fewer job opportunities outside the home that would allow for participation and create a sense of efficacy (Pateman, 1970).

Structural violence creates the foundation for structural inequality and conflicts. Structural inequality refers to the system of privilege and inequality created and maintained by interlocking societal institutions. Women are subjected to "structural inequality" which results from men domination, gender stereotypes, sexism, lack of opportunities and decisionmaking power, under-education, obstacles in access to social resources or access to economic resources, and all other aspects resulting from non- or under-participation of women. Caprioli (2005) argued that gender inequality should have a substantial impact on intrastate conflict based on the direct impact of structural inequality with its inherent norms of discrimination and violence and the role that structural inequality has in facilitating ethnic rebellion and conflict. Moreover, gender discrimination and structural violence are important aspects in mobilizing groups and in legitimizing violence. Inequality between groups can create grievances which, especially when exploited by politicians, deepen animosity between them and increase the likelihood of bloodshed (Atwood, 2012). In the same vein, Midlarsky (1999) highlighted that inequality, when extreme and systematic, leads to political violence. From this perspective, norms of equality facilitate cooperation among groups who are then more 
likely to rely on influence or persuasion, rather than on violence (Caprioli, 2005; Ross, 2000).

\section{Norms and social roles}

The second mechanism is about the norms and social roles of men and women. In many societies, the roles and responsibilities imposed on the people are divided into male and female gender roles. The argument is that gender equality as a norm is associated with low occurrence of violence. Existing work associates women with an aversion to violence and an inclination toward peace and argues that including women in society makes violent conflict less likely (Demeritt et al. 2014).

In general, women are more violence averse. Hudson et al. (2008-2009); Hudson and den Boer (2012) argued that societies dominated and controlled by men are subject to an environment where violence and domination are considered as normal. Thus, societies with a very high level of male dominance in politics tend to be dominated by hypermasculine political cultures, which can probably fuel electoral violence. This norm prescribes violence as a means to resolve conflict also on the highest decision-making levels (Forsberg and Olsson, 2016). This is typically the case for electoral violence where some groups do not accept the poll results nor adhere to the democratic process, and resort to violence to achieve their ends. Wolfgang and Ferracuti (1967) used the concept of 'subculture of violence' perspective to emphasize that social groups exhibit high rates of violent behavior because of group members' adherence to values and norms that support, legitimize, and encourage violent behavior, often involving an emphasized ideal of masculinity.

In this regard, gender equality is associated with lower grievances and conflicts. Societies characterized by gender equality are ingrained with norms that prescribe that men and women treat each other with respect (Melander 2005A, 2005B). These norms then transfer to other societal relations, such as between ethnic groups and political parties, and can explain the relative peacefulness of such states. Demeritt et al. (2014) argued that gender equality as a norm prescribes respect and resolution of conflict without violence, and hence equality 
norms may prevent grievances from escalating to violent conflict in the first place. Incorporating women in society reflects changes in gender construction and particularly reflect the relaxation of the norm of men-as-warriors. From this perspective, states that emphasize gender equality and female participation in traditionally male society also tend to adopt more generally peaceful preferences, leading to a reduced likelihood of political violence (Demeritt et al., 2014; Goldstein, 2001). Accordingly, including women in societal decision-making, they will increasingly exert the inherent pacific influence and/or redefine traditional gender roles in a way that privileges nonviolence in the way constructivists anticipate. Asal et al. (2013) found that groups that proscribe a gender-inclusive ideology are less likely to pursue their objectives using violent means. Similarly, Tessler and Warriner (1997) and Conover and Sapiro (1993) highlighted that gender-equal attitudes are correlated with advocating peaceful conflict resolution.

Some authors rely on the biological and reproductive role of women to explain the peaceful attitudes of women. This leads to an inclination to give life, and not take it (Demeritt et al., 2014; Smith, 2001). With this natural preference for peace, women would prefer to prevent societal problems from escalating to conflict and attempt to de-escalate armed conflicts when they do occur (O’Mahoney, 2012; Sayer, 1997).

However, women can also act as perpetrators of violence. According to Ortbals and PoloniStaudinger (2018), women can participate in violent operations through support such as food preparation, the storage and transport of weapons, and can alternate between support, combat roles and leadership. There are two arguments on the reasons of the recourse of violence by women. First, some authors claimed that improvements in women's societal and political position led to an increase in their perpetration of violence (Bardall, 2011; Adler, 1975). Bardall (2011) revealed that in many countries transitioning to democracy, women used violence as a mean to voice their concerns and acted as perpetrators in almost 25 percent of incidents in 2005. Chesney-Lind $(1986,2006)$ observed that the increase in women's involvement in violent crime tend to follow the logic that women's liberation causes women to start acting like men. Georges-Abeyie (1983) argued that the emancipation accompanies women's involvement in conflicts. Second, other studies suggest that women are using 
violence as a form of self-defense. Allen, Swan and Raghavan (2009), and Moen, Lennart and Edin (2016) found that violence perpetrated by women in intimate partner relationships is often associated with their victimization by male partners. Bloom (2011) argued that women across a number of conflicts tend to be motivated by the four Rs: revenge (for death of a family member), redemption (for past sins that have damaged their self-image), relationship (with insurgents, such as a father or husband), and respect (from their community for their dedication to the cause).

\section{DATA SOURCES AND DESCRIPTIVE STATISTICS}

\section{A. Data sources}

The primary data source used in this paper is the round 6 of Afrobarometer surveys. The Afrobarometer is an independent, nonpartisan research project that measures the social, political, and economic conditions in Africa. Beginning in 1999 with only 12 countries in the first round, the Afrobarometer surveys covered 36 countries in the sixth round conducted in 2014/2015. ${ }^{2}$ The sixth round is the latest available, and we will use the results of this round in this paper. Nationally representative samples of individuals who are more than 18 years old are selected both in rural and urban areas of the different countries. Afrobarometer uses multilevel random selection methods to generate the samples, which are representative crosssection of the population. Thus, Afrobarometer represents a strong, reliable source of public opinion data within African states. In the sixth wave, more than 53000 people have been surveyed, with sample sizes ranging between 1200 and 2400 people in function of each country population size.

\footnotetext{
2 Taking into account the year of the survey does not change the results.
} 


\section{Measurement of electoral violence}

We use the survey data to measure election related violence. The main issue that arises is the definition per se of electoral violence. The United Nations Development Program (UNDP) (2009) defines electoral violence as "Acts or threats of coercion, intimidation, or physical harm perpetrated to affect an electoral process or that arise in the context of electoral competition. When perpetrated to affect an electoral process, violence may be employed to influence the process of elections—such as efforts to delay, disrupt, or derail a poll-and to influence the outcomes: the determining of winners in competitive races for political office or to secure approval or disapproval of referendum questions.” Similarly, Fischer (2002) defines electoral violence as any random or organized act or threat to intimidate, physically harm, blackmail, or abuse a political stakeholder in seeking to determine, delay, or to otherwise influence an electoral process. As such, electoral violence includes acts, such as assassination of opponents or spontaneous fisticuffs between rival groups of supporters - and threats, coercion, and intimidation of opponents, voters, or election officials (UNDP, 2009). Threat and intimidation are forms of coercion that are just as powerful as acts of violence can be. Indeed, one purpose of acts of broader intimidation - such as tossing a grenade into a crowd of rival supporters - is to induce fear and to intimidate (e.g., to suppress mobilization or voting by that group). Höglund (2009) include activities like "harassing, assault, and intimidation of candidates, election workers, and voters; rioting, destruction of property; and political assassination" (Höglund, 2009: 417). Electoral violence can occur before, during or after elections.

In the sixth round of Afrobarometer surveys, there are several questions that are related to elections in Africa. To measure electoral violence, we relied on questions Q49 and Q48F. In the question Q49, the respondents are asked "During election campaigns in this country, how much do you personally fear becoming a victim of political intimidation or violence?". Responses include 'A lot', 'Somewhat', 'A little bit', and 'Not at all'. We merge the three first answers and code them as 1 , which indicates that the respondent fears becoming victim 
of political intimidation or violence, and 0 for the last answer 'Note at all'. ${ }^{3}$ As for the question $(\mathrm{Q} 48 \mathrm{~F})$, the respondents are asked "In your opinion, how often do the following things occur in this country's elections: Voters are threatened with violence at the polls". Responses include 'Sometimes', 'Often', 'Always', 'Never'. Likewise, we merge the first three answers and code them as 1 , which implies that electoral violence happens in the country, and 0 for the last answer "Never". As can be observed, these questions clearly refer to electoral violence according to the definitions highlighted above (UNDP, 2009). In this paper, we base our analysis on the first question (Q49). It provides an assessment about the respondent personal experience or perception regarding political intimidation and violence, compared to the second question $(\mathrm{Q} 48 \mathrm{~F})$ which is more about whether electoral violence happens in the country. However, we will use the second question in robustness check.

\section{Measurement of gender equality}

We turn now to the measurement of gender equality. There are several measures of gender equality in the literature (see for a review Stotsky et al. 2016), including the female labor force participation rate, the female to male labor force participation ratio, gender pay gap, the fertility rate, and so on. In this paper, we use the female-to-male labor force participation ratio as a measure of gender equality for which we have the data in the sixth round of Afrobarometer surveys $^{4}$. The female-to-male labor force participation ratio is the ratio between the female labor force participation rate and the male labor force participation rate. We resort to question Q95 where respondents are asked about their job status "Do you have a job that pays a cash income?". The survey also includes the gender of the respondent (see question Q101), which allows us to calculate the female labor force participation rate and the male labor force participation rate for each administrative region. We then calculate the ratio between the two to get the female-to-male labor force participation ratio. Furthermore, we use the female labor force participation rate as an alternative measure of gender equality in

\footnotetext{
${ }^{3}$ The results remain consistent even if we consider the intensity of electoral violence.

${ }^{4}$ The survey does not contain any data on income, and thus gender pay gap cannot be used.
} 
robustness check, following previous on gender equality and conflicts (Caprioli 2000, 2005; Demeritt et al. 2014).

\section{Control variables}

We finally control for several variables to alleviate problems of confounding caused by omitted variables.

The sociodemographic variables include:

- Age: continuous variable (in years)

- Education: dichotomous variable taking the value of 1 if the respondent has a tertiary education degree, and 0 otherwise

- Urban: dichotomous variable taking the value of 1 if the respondent resides in urban area, and 0 otherwise

- Employed: dichotomous variable taking the value of 1 if the respondent is employed, and 0 otherwise

Political affiliation and Election-related variables include:

- Political party member: dichotomous variable taking the value of 1 if the respondent is affiliated to a political party, and 0 otherwise

- Public affairs interests: dichotomous variable taking the value of 1 if the respondent is interested in public affairs, and 0 otherwise.

- Voted: dichotomous variable taking the value of 1 if the respondent voted during the last election and 0 otherwise

- Fair election: dichotomous variable taking the value of 1 if the respondent thinks that the last election was completely free and fair, and 0 otherwise.

- Voters' views reflected: dichotomous variable taking the value of 1 if the respondent thinks that elections ensure that voters' views are reflected, and 0 otherwise 
- Votes counted fairly: dichotomous variable taking the value of 1 if the respondent thinks that votes are always counted fairly, and 0 otherwise

- Media fair coverage: dichotomous variable taking the value of 1 if the respondent thinks that the media provides fair coverage of all candidates during the last election, and 0 otherwise.

- Non-participation of opposition parties: dichotomous variable taking the value of 1 if the respondent thinks that opposition has been prevented from running, and 0 otherwise

Trust in institutions and people involved in election organization variables ${ }^{5}$

- Trust electoral commission: dichotomous variable taking the value of 1 if the respondent trusts the national electoral commission, and 0 otherwise

- Trust government: dichotomous variable taking the value of 1 if the respondent trusts the elected local government council, and 0 otherwise

- Trust ruling party: dichotomous variable taking the value of 1 if the respondent trusts the ruling party, and 0 otherwise

- Trust police: dichotomous variable taking the value of 1 if the respondent trusts the police, and 0 otherwise

- Trust army: dichotomous variable taking the value of 1 if the respondent trusts the army, and 0 otherwise

- Trust courts of law: dichotomous variable taking the value of 1 if the respondent trusts the courts of law, and 0 otherwise.

Media-related variables:

\footnotetext{
${ }^{5}$ The results do not change even if these variables are included separately.
} 
- Radio: dichotomous variable taking the value of 1 if the respondent gets news from the radio, 0 otherwise

- TV: dichotomous variable taking the value of 1 if the respondent gets news from TV, and 0 otherwise

- Newspapers: dichotomous variable taking the value of 1 if the respondent gets news from the newspapers, and 0 otherwise

- Social media: dichotomous variable taking the value of 1 if the respondent gets news from the social media, and 0 otherwise

Socioeconomic variables include:

- Access to food: dichotomous variable taking the value of 1 if the respondent has never been without food, and 0 otherwise

- Access to water: dichotomous variable taking the value of 1 if the respondent has never been without water, and 0 otherwise

- Access to medical care: dichotomous variable taking the value of 1 if the respondent has never been without medical care, and 0 otherwise

- Access to cash income: dichotomous variable taking the value of 1 if the respondent has never been without cash income, and 0 otherwise

- Access to transportation: dichotomous variable taking the value of 1 if the respondent has access to transportation, and 0 otherwise.

- Access to electricity: dichotomous variable taking the value of 1 if the respondent has access to electricity, and 0 otherwise.

\section{Our instrumental variable}

We instrument the female-to-male labor force participation ratio with the growth in rainfalls between 2013 and 2014. The data on rainfalls are extracted from Ben Yishay et al, 2017, which provides geocoded data at various geographic levels, including the administrative regions/provinces. Rainfalls data of Ben Yishay et al (2017) are originally from the 
Combined Precipitation Dataset of NASA's Global Precipitation Climatology Project (Willmott and Matsuura, 2001). Station values of annual total raingage-measured precipitation were interpolated to a 0.5 degree by 0.5 degree latitude/longitude grid, where the grid nodes are centered on the 0.25 degree. The main advantage of Ben Yishay et al (2017) geocoded data is that they provide time series data of precipitations for each administrative level, which can then be matched with the respondent's administrative region as coded by Afrobarometer. Therefore, all respondents within the region would be matched with the rainfalls level recorded by Ben Yishay et al (2017). We were able to match the administrative region names for 30 countries out of the 36 countries in the sixth round of Afrobarometer surveys. Only the administrative regions of Egypt and Uganda did not match with the region names in Ben Yishay et al (2017). These countries are thus excluded from the study. Furthermore, there is a lack of rainfalls data at the regional level for Botswana, Cabo Verde, Lesotho, and Sao Tome and Principe. These countries are thereby not included in the study.

\section{B. Descriptive statistics}

Our final sample covers 30 countries and consists of more than 40,000 respondents. The sample sizes range from 630 people in Liberia to 2395 in Malawi. Table 1 displays some descriptive statistics. On average, 46 percent of total respondents reported being a victim of electoral violence. Furthermore, the female to male labor force participation ratio is on average 73 percent. Thus, around 73 women of the sample are working per every group of 100 working men. This share differs widely between countries. Figure 1 presents the average values of female-to-male labor force participation ratio (our gender equality index) and electoral violence by country. Figure 1 shows that electoral violence is widespread in Nigeria, Cote d'Ivoire, Liberia, and Kenya where more than two-thirds of respondents reported being victim of political intimidation and violence. On the contrary, the share of respondents who have been targeted by electoral violence is low in Niger, Madagascar, Mauritius and Burkina Faso. In these countries, less than one-fourth of respondents reported being subjects of electoral violence. Regarding the female-to-male labor force participation ratio, it is high in Mozambique, Ghana, Togo, and Madagascar where the ratio is above 90 
percent, and low in Niger, Burundi, Tunisia, Algeria and Malawi where the female-to-male labor force participation ratio is below 50 percent.

Table 1: Descriptive statistics

\begin{tabular}{|c|c|c|c|c|c|}
\hline Variable & Obs & Mean & Std. Dev. & Min & $\operatorname{Max}$ \\
\hline Electoral violence & 40,034 & 0.46 & 0.5 & 0 & 1 \\
\hline Gender equality & 40,034 & 0.73 & 0.3 & 0 & 3 \\
\hline Employed & 39,875 & 0.39 & 0.5 & 0 & 1 \\
\hline Education & 39,932 & 0.09 & 0.3 & 0 & 1 \\
\hline Age & 39,830 & 37.31 & 14.3 & 18 & 105 \\
\hline Urban & 40,034 & 0.39 & 0.5 & 0 & 1 \\
\hline Political party member & 36,708 & 0.63 & 0.5 & 0 & 1 \\
\hline Voted & 37,956 & 0.70 & 0.5 & 0 & 1 \\
\hline Fair election & 36,611 & 0.44 & 0.5 & 0 & 1 \\
\hline Voters' views reflected & 32,899 & 0.37 & 0.5 & 0 & 1 \\
\hline Votes counted fairly & 37,377 & 0.35 & 0.5 & 0 & 1 \\
\hline Media fair coverage & 36,012 & 0.25 & 0.4 & 0 & 1 \\
\hline Non-participation of opposition parties & 36,237 & 0.07 & 0.3 & 0 & 1 \\
\hline Public affairs interests & 39,763 & 0.56 & 0.5 & 0 & 1 \\
\hline Trust electoral commission & 36,910 & 0.27 & 0.4 & 0 & 1 \\
\hline Trust government & 38,471 & 0.22 & 0.4 & 0 & 1 \\
\hline Trust ruling party & 36,639 & 0.24 & 0.4 & 0 & 1 \\
\hline Trust police & 39,432 & 0.26 & 0.4 & 0 & 1 \\
\hline Trust army & 38,925 & 0.41 & 0.5 & 0 & 1 \\
\hline Trust courts of law & 38,680 & 0.27 & 0.4 & 0 & 1 \\
\hline Radio & 39,985 & 0.82 & 0.4 & 0 & 1 \\
\hline TV & 39,963 & 0.60 & 0.5 & 0 & 1 \\
\hline Newspapers & 39,842 & 0.40 & 0.5 & 0 & 1 \\
\hline Social media & 39,427 & 0.25 & 0.4 & 0 & 1 \\
\hline Access to food & 39,974 & 0.54 & 0.5 & 0 & 1 \\
\hline Access to water & 39,972 & 0.54 & 0.5 & 0 & 1 \\
\hline Access to medical care & 39,915 & 0.50 & 0.5 & 0 & 1 \\
\hline Access to cash income & 39,888 & 0.25 & 0.4 & 0 & 1 \\
\hline Access to transportation & 39,885 & 0.82 & 0.4 & 0 & 1 \\
\hline Access to electricity & 40,026 & 0.63 & 0.5 & 0 & 1 \\
\hline Rainfall growth & 40,034 & 0.04 & 0.3 & -0.8 & 4.2 \\
\hline
\end{tabular}


Figure 1: Gender equality and electoral violence per country (average values)

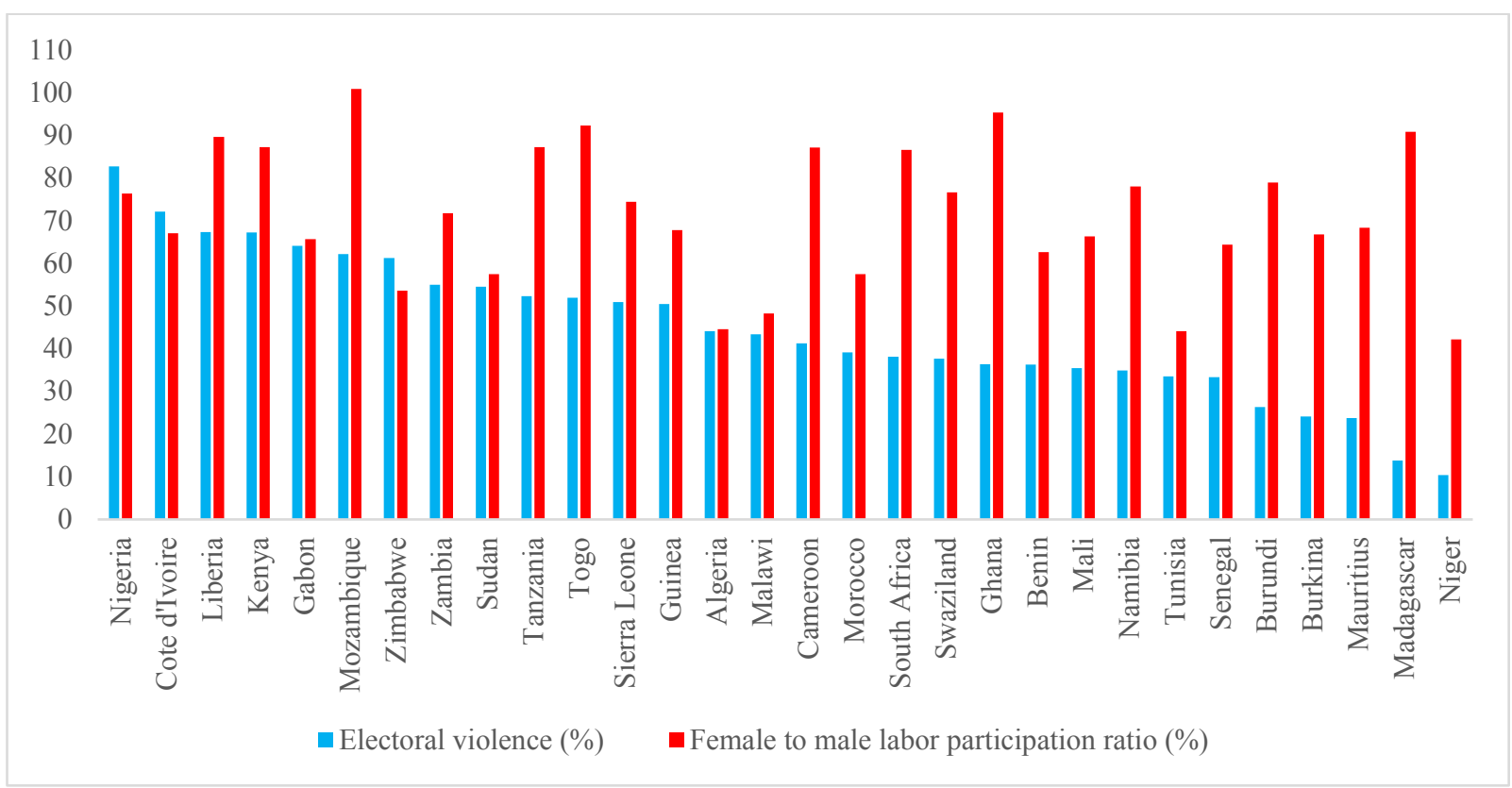

Figure 2 presents the relationship between female-to-male labor force participation ration and rainfall growth. As expected, there is a positive correlation between female-to-male labor force participation ratio and rainfall growth.

Figure 2: Relationship between female-to-male labor force participation ratio and growth in rainfall

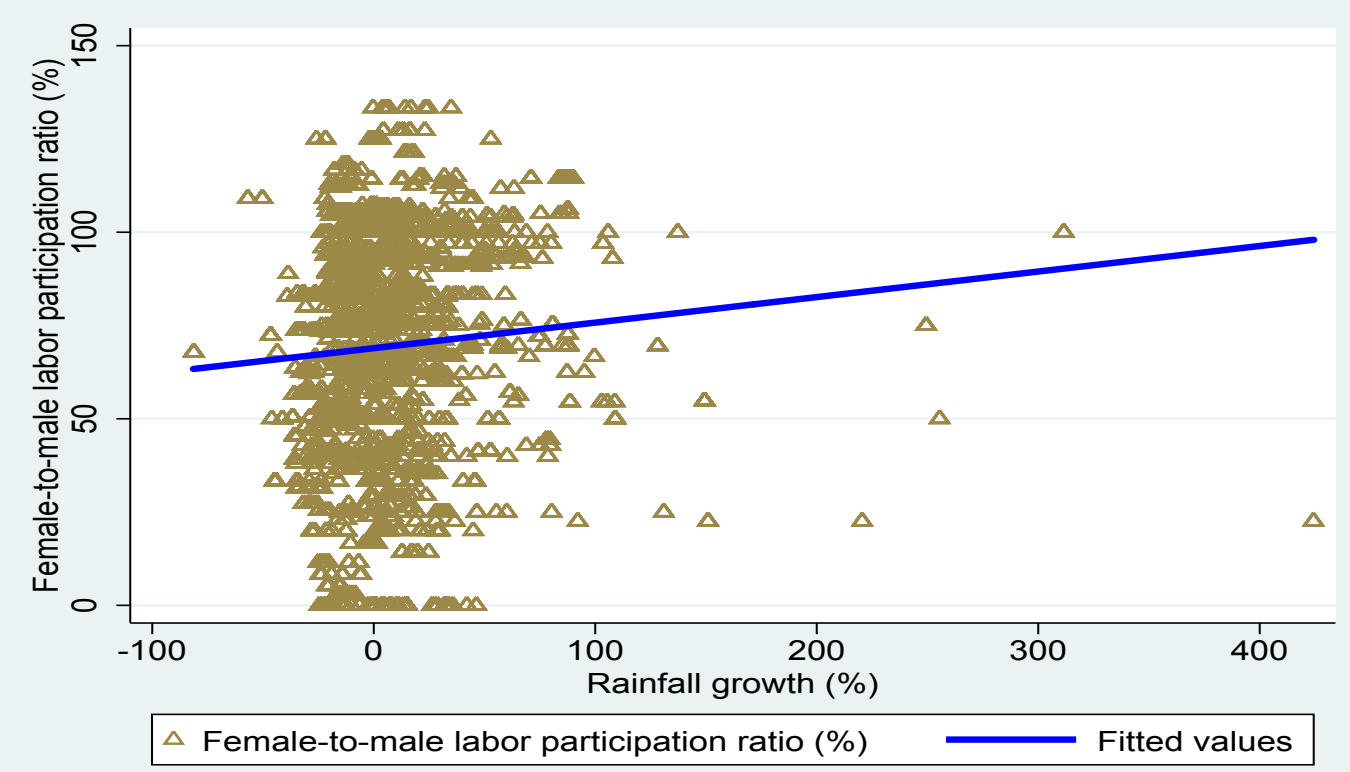




\section{EMPIRICAL STRATEGY}

Our objective is to estimate the impact of gender equality on electoral violence. The model to be estimated is as follows:

Electoral Violence $_{i j}=\alpha+\beta$ Gender Equality ${ }_{i j}+\gamma X_{i j}^{\prime}+\pi_{j}+\mu_{i j}$

Where, for individual $i$ from country $j$, Electoral Violence $e_{i j}$ is a binary variable taking the value of 1 if the respondent reports being victim of electoral violence, Gender Equality ${ }_{i j}$ represents the female-to-male labor force participation ratio. Vector $X^{\prime}{ }_{i j}$ includes socio economic and demographic, political, and election-related variables. $\pi_{j}$ are country fixed effects. The inclusion of country fixed effects will account for observable and unobservable country-specific characteristics that may explain electoral violence. $\mu_{i j}$ is the error term.

Attempts to estimate the impact of gender equality on election related violence will suffer from endogeneity issues. The direction, and the magnitude of this bias will depend on the relative and potentially offsetting effects of reverse causality and measurement error. The most problematic issue arises from reverse causality given that election related violence may affect the participation of women in the labor market (our gender equality index). The direction of this bias is negative most likely given that electoral violence might impact negatively female-to-male labor force participation ratio as the economic activity shrinks. On the second bias related to the measurement error, it may come from any of the control variables, including gender equality. Another source of endogeneity is the omitted variables. It is hard to delineate the specific points related to electoral violence. Thus, controlling for all possible determinants of electoral violence in one regression is unconceivable. Consequently, OLS regressions are likely to be biased.

In order to address this endogeneity issue, we employ an instrumental variable probit model to estimate equation (1). We use the exogenous variations in rainfalls as instrument for female-to-male labor force participation ratio. The idea is that an economic shock emerging from extreme rainfalls will lead to a loss of jobs for women, thus affecting the female-tomale labor force participation ratio, and, consequently, trigger electoral violence. An extreme 
economic shock steaming from a decline in rainfall may disproportionally affect women compared to men as men could have more alternative solutions than women. Several studies have shown that women's job mobility and transition tend to be low compared to men (Felmlee, 1982; Hsueh and Tienda, 1996; Fuller, 2008; Looze, 2017). Royalty (1998) found that women are more likely than men to experience job-to-nonemployment rather than jobto-job transitions. This, in turn, implies that the unemployment rate for women will be higher than men when an adverse shock in rainfall materializes.

Following this literature, we use rainfalls growth between 2013 and 2014 to instrument for female-to-male labor force participation ratio. The intuition is that there is a strong link between rainfalls and job opportunities in Africa as several people still depend heavily on the agriculture sector. Weather shocks are plausible instruments for developments in the labor markets in economies that largely rely on rainfed agriculture (Miguel et al. 2004). Agriculture remains the most important economic activity in several African countries. Indeed, the agriculture sector accounts for between 30 and 40 percent of GDP in Africa, and the sector is a leading source of jobs for over two-thirds of Africa's population (World Bank, 2013). Moreover, women make up almost 50 percent of the agriculture labor force in Africa (FAO, 2011), with the share varying across countries, from $24 \%$ in Niger to $56 \%$ in Uganda. As a consequence, a decline in rainfalls could result in a loss of economic activities and jobs for women, thus increasing gender inequality, and triggering civil violence. In our sample, the coefficient of correlation between female labor force participation and rainfall growth is 72 percent.

As in Miguel et al (2004), we recognize that there are several alternative causal paths, aside from the labor market mechanism, through which shock in rainfall could also lead to civil violence. Beyond the loss of jobs, one might argue that shocks in rainfall can have an impact on transportation, inflation, the access to electricity and thus affect voter turnout. We controlled for these alternative causal channels: transportation, voter turnout, employment status, electricity, inflation, and income inequality, but doing this does still not guarantee that the exclusion criteria is fully met. Therefore, we remain cautious that our results may not fully imply causation between gender equality and electoral violence and are interpreted as correlations. 


\section{RESUlTS}

Results are reported in Table 2. We report in columns (1)-(5) the results of the simple probit model, and in columns (6)-(10) the results using the instrumental variable probit model. From the outset, we observe that the coefficient associated with gender equality is negative and significant in all columns, suggesting that gender equality is negatively associated with electoral violence. We will focus our analysis on the instrumental variable probit model. The results in columns (6)-(10) suggest that our instrument performs very well in the first stage. Rainfall growth is a positive and significant predictor of female labor force participation in Africa. Statistical tests do not invalidate the econometric method. At the bottom of the table is Wald chi(2) score of the exogeneity of the instrumented variable. We reject the null hypothesis of no endogeneity. The Wald-test and the Anderson-Rubin test regarding the strength of the instrument are strongly significant, therefore we reject the hypothesis that the instrument is weak.

We report in column (6) the results of the estimates without any control variables, except our variable of interest. Country fixed effects are included in all regressions with the purpose of controlling for all co-determinants of electoral violence and gender equality. We observe that the coefficient associated with gender equality-female-to-male labor force participation ratio, our coefficient of interest, is negative and significant at the 5 percent level. Thus, an increase in gender equality reduces the likelihood of electoral violence. Quantitatively, an increase in female-to-male labor force participation ratio by 1 percent is correlated with a decrease in the likelihood of electoral violence by 4.2 percent $^{6}$. Our results are consistent with some previous studies that highlighted that gender equality is negatively associated with the occurrence of conflicts (Demeritt et al., 2014; Caprioli 2000, 2005).

In column (7) we include some basic socio-demographic variables, including respondents' level of education, age, living area, and employment status. As shown by the coefficient associated with the gender equality index, we still detect a negative correlation between gender equality and electoral violence. Moreover, the coefficient associated with education,

\footnotetext{
${ }^{6}$ Marginal effect calculated at mean values.
} 
and age are negative and strongly significant, suggesting that people who are highly educated and more aged are less likely to report electoral violence. 
Table 2: Baseline results

\begin{tabular}{|c|c|c|c|c|c|c|c|c|c|c|}
\hline \multirow[t]{2}{*}{ VARIABLES } & (1) & (2) & (3) & (4) & $(5)$ & $(6)$ & $(7)$ & $(8)$ & $(9)$ & $(10)$ \\
\hline & \multicolumn{5}{|c|}{ Probit } & \multicolumn{5}{|c|}{ IV probit } \\
\hline Gender equality & $\begin{array}{c}-0.073 * * * \\
(0.020)\end{array}$ & $\begin{array}{c}-0.075^{* * *} \\
(0.020)\end{array}$ & $\begin{array}{c}-0.084 * * * \\
(0.029)\end{array}$ & $\begin{array}{c}-0.077 * * * \\
(0.029)\end{array}$ & $\begin{array}{c}-0.076^{* * *} \\
(0.029)\end{array}$ & $\begin{array}{c}-1.313 * * \\
(0.610)\end{array}$ & $\begin{array}{l}-1.233^{*} \\
(0.664)\end{array}$ & $\begin{array}{c}-1.394 * * * \\
(0.511)\end{array}$ & $\begin{array}{c}-1.470 * * * \\
(0.531)\end{array}$ & $\begin{array}{c}-1.661 * * * \\
(0.480)\end{array}$ \\
\hline Employed & & $\begin{array}{c}0.044 \\
(0.035)\end{array}$ & $\begin{array}{c}0.033 \\
(0.021)\end{array}$ & $\begin{array}{c}0.036 \\
(0.028)\end{array}$ & $\begin{array}{c}0.028 \\
(0.018)\end{array}$ & & $\begin{array}{c}0.019 \\
(0.033)\end{array}$ & $\begin{array}{c}0.026 \\
(0.028)\end{array}$ & $\begin{array}{c}0.019 \\
(0.029)\end{array}$ & $\begin{array}{c}0.036 \\
(0.027)\end{array}$ \\
\hline Education & & $\begin{array}{c}-0.079 * * * \\
(0.021)\end{array}$ & $\begin{array}{c}-0.120 * * * \\
(0.028)\end{array}$ & $\begin{array}{c}-0.117^{* * *} \\
(0.029)\end{array}$ & $\begin{array}{c}-0.103 * * * \\
(0.029)\end{array}$ & & $\begin{array}{c}-0.065^{* * *} \\
(0.023)\end{array}$ & $\begin{array}{c}-0.116^{* * *} \\
(0.031)\end{array}$ & $\begin{array}{c}-0.138^{* * *} \\
(0.032)\end{array}$ & $\begin{array}{c}-0.118^{* * *} \\
(0.032)\end{array}$ \\
\hline Age & & $\begin{array}{c}-0.005^{* * *} \\
(0.000)\end{array}$ & $\begin{array}{c}-0.003 * * * \\
(0.001)\end{array}$ & $\begin{array}{c}-0.004 * * * \\
(0.001)\end{array}$ & $\begin{array}{c}-0.004 * * * \\
(0.001)\end{array}$ & & $\begin{array}{c}-0.006^{* * *} \\
(0.001)\end{array}$ & $\begin{array}{c}-0.004 * * * \\
(0.001)\end{array}$ & $\begin{array}{c}-0.004 * * * \\
(0.001)\end{array}$ & $\begin{array}{c}-0.004 * * * \\
(0.001)\end{array}$ \\
\hline Urban & & $\begin{array}{c}0.003 \\
(0.013)\end{array}$ & $\begin{array}{c}0.061 * * * \\
(0.017)\end{array}$ & $\begin{array}{c}0.063^{* * *} \\
(0.019)\end{array}$ & $\begin{array}{c}0.055^{* * * *} \\
(0.020)\end{array}$ & & $\begin{array}{l}0.037^{*} \\
(0.019)\end{array}$ & $\begin{array}{l}-0.031 \\
(0.024)\end{array}$ & $\begin{array}{c}-0.049 * \\
(0.025)\end{array}$ & $\begin{array}{c}0.008 \\
(0.032)\end{array}$ \\
\hline Political party member & & & $\begin{array}{c}0.015 \\
(0.019)\end{array}$ & $\begin{array}{c}0.021 \\
(0.019)\end{array}$ & $\begin{array}{c}0.024 \\
(0.019)\end{array}$ & & & $\begin{array}{c}0.026 \\
(0.021)\end{array}$ & $\begin{array}{c}0.018 \\
(0.021)\end{array}$ & $\begin{array}{c}0.012 \\
(0.021)\end{array}$ \\
\hline Voted & & & $\begin{array}{c}-0.065^{* * *} \\
(0.019)\end{array}$ & $\begin{array}{c}-0.066^{* * *} \\
(0.019)\end{array}$ & $\begin{array}{c}-0.064 * * * \\
(0.020)\end{array}$ & & & $\begin{array}{c}-0.062^{* * * *} \\
(0.022)\end{array}$ & $\begin{array}{c}-0.062^{* * *} \\
(0.023)\end{array}$ & $\begin{array}{c}-0.060 * * * \\
(0.022)\end{array}$ \\
\hline Fair election & & & $\begin{array}{c};-0.302^{* * *} \\
(0.019)\end{array}$ & $\begin{array}{c}-0.304 * * * \\
(0.019)\end{array}$ & $\begin{array}{c}-0.295^{* * *} \\
(0.019)\end{array}$ & & & $\begin{array}{c}-0.326^{* * *} \\
(0.031)\end{array}$ & $\begin{array}{c}-0.323^{* * *} \\
(0.033)\end{array}$ & $\begin{array}{c}-0.304 * * * \\
(0.033)\end{array}$ \\
\hline Voters' views reflected & & & $\begin{array}{c}-0.086^{* * *} \\
(0.017)\end{array}$ & $\begin{array}{c}-0.085^{* * *} * \\
(0.018)\end{array}$ & $\begin{array}{c}-0.076^{* * * *} \\
(0.018)\end{array}$ & & & $\begin{array}{l}-0.029 \\
(0.019)\end{array}$ & $\begin{array}{l}-0.029 \\
(0.019)\end{array}$ & $\begin{array}{l}-0.017 \\
(0.019)\end{array}$ \\
\hline Votes counted fairly & & & $\begin{array}{c}-0.235^{* * *} \\
(0.022)\end{array}$ & $\begin{array}{c}-0.236^{* * *} \\
(0.022)\end{array}$ & $\begin{array}{c}-0.231 * * * \\
(0.022)\end{array}$ & & & $\begin{array}{c}-0.235 * * * \\
(0.029)\end{array}$ & $\begin{array}{c}-0.234 * * * \\
(0.030)\end{array}$ & $\begin{array}{c}-0.224 * * * \\
(0.030)\end{array}$ \\
\hline Media fair coverage & & & $\begin{array}{c}0.014 \\
(0.022)\end{array}$ & $\begin{array}{c}0.015 \\
(0.022)\end{array}$ & $\begin{array}{c}0.016 \\
(0.022)\end{array}$ & & & $\begin{array}{l}-0.032 \\
(0.026)\end{array}$ & $\begin{array}{l}-0.035 \\
(0.026)\end{array}$ & $\begin{array}{r}-0.030 \\
(0.026)\end{array}$ \\
\hline Non-participation of opposition parties & & & $\begin{array}{c}0.274 * * * \\
(0.034)\end{array}$ & $\begin{array}{c}0.274 * * * \\
(0.034)\end{array}$ & $\begin{array}{c}0.261^{* * *} \\
(0.034)\end{array}$ & & & $\begin{array}{c}0.159 * * * \\
(0.040)\end{array}$ & $\begin{array}{c}0.161 * * * \\
(0.041)\end{array}$ & $\begin{array}{c}0.140^{* * *} \\
(0.040)\end{array}$ \\
\hline Public affairs interests & & & $\begin{array}{c}-0.034 * * \\
(0.017)\end{array}$ & $\begin{array}{c}-0.038^{* *} \\
(0.017)\end{array}$ & $\begin{array}{c}-0.035^{* *} \\
(0.017)\end{array}$ & & & $\begin{array}{c}-0.038^{* *} \\
(0.019)\end{array}$ & $\begin{array}{c}-0.053 * * * \\
(0.019)\end{array}$ & $\begin{array}{c}-0.052 * * * \\
(0.019)\end{array}$ \\
\hline Trust electoral commission & & & $\begin{array}{c}-0.099^{* * * *} \\
(0.026)\end{array}$ & $\begin{array}{c}-0.098^{* * *} \\
(0.026)\end{array}$ & $\begin{array}{c}-0.096^{* * * *} \\
(0.026)\end{array}$ & & & $\begin{array}{c}-0.077^{* * * *} \\
(0.029)\end{array}$ & $\begin{array}{c}-0.074 * * \\
(0.029)\end{array}$ & $\begin{array}{c}-0.068^{* *} \\
(0.029)\end{array}$ \\
\hline Trust government & & & $\begin{array}{l}-0.011 \\
(0.027)\end{array}$ & $\begin{array}{l}-0.011 \\
(0.028)\end{array}$ & $\begin{array}{l}-0.016 \\
(0.028)\end{array}$ & & & $\begin{array}{l}-0.017 \\
(0.029)\end{array}$ & $\begin{array}{l}-0.015 \\
(0.029)\end{array}$ & $\begin{array}{c}-0.012 \\
(0.029)\end{array}$ \\
\hline Trust ruling party & & & $\begin{array}{c}0.026 \\
(0.027)\end{array}$ & $\begin{array}{c}0.023 \\
(0.027)\end{array}$ & $\begin{array}{c}0.017 \\
(0.027)\end{array}$ & & & $\begin{array}{l}-0.054^{*} \\
(0.028)\end{array}$ & $\begin{array}{c}-0.048^{*} \\
(0.028)\end{array}$ & $\begin{array}{l}-0.040 \\
(0.028)\end{array}$ \\
\hline Trust police & & & $\begin{array}{c}-0.036 \\
(0.028)\end{array}$ & $\begin{array}{c}-0.042 \\
(0.028)\end{array}$ & $\begin{array}{c}-0.043 \\
(0.028)\end{array}$ & & & $\begin{array}{c}0.039 \\
(0.029)\end{array}$ & $\begin{array}{c}0.048 \\
(0.029)\end{array}$ & $\begin{array}{l}0.050^{*} \\
(0.029)\end{array}$ \\
\hline Trust army & & & $\begin{array}{c}-0.086^{* * *} \\
(0.023)\end{array}$ & $\begin{array}{c}-0.089^{* * *} \\
(0.023)\end{array}$ & $\begin{array}{c}-0.087^{* * *} \\
(0.023)\end{array}$ & & & $\begin{array}{c}-0.114 * * * \\
(0.024)\end{array}$ & $\begin{array}{c}-0.124 * * * \\
(0.025)\end{array}$ & $\begin{array}{c}-0.123 * * * \\
(0.025)\end{array}$ \\
\hline Trust courts of law & & & $\begin{array}{l}-0.013 \\
(0.026)\end{array}$ & $\begin{array}{l}-0.011 \\
(0.026)\end{array}$ & $\begin{array}{l}-0.008 \\
(0.027)\end{array}$ & & & $\begin{array}{c}-0.004 \\
(0.028)\end{array}$ & $\begin{array}{l}-0.002 \\
(0.028)\end{array}$ & $\begin{array}{c}-0.003 \\
(0.027)\end{array}$ \\
\hline Radio & & & & $\begin{array}{c}0.04 \\
(0.025)\end{array}$ & $\begin{array}{l}0.051^{* *} \\
(0.025)\end{array}$ & & & & $\begin{array}{c}0.074 * * * \\
(0.026)\end{array}$ & $\begin{array}{c}0.083 * * * \\
(0.026)\end{array}$ \\
\hline TV & & & & $\begin{array}{c}0.023 \\
(0.023)\end{array}$ & $\begin{array}{c}0.008 \\
(0.024)\end{array}$ & & & & $\begin{array}{c}0.007 \\
(0.025)\end{array}$ & $\begin{array}{c}0.055^{* *} \\
(0.027)\end{array}$ \\
\hline Newspapers & & & & $\begin{array}{c}0.077 * * * \\
(0.022)\end{array}$ & $\begin{array}{c}0.085 * * * \\
(0.022)\end{array}$ & & & & $\begin{array}{c}0.084 * * * \\
(0.027)\end{array}$ & $\begin{array}{c}0.093 * * * \\
(0.027)\end{array}$ \\
\hline Social media & & & & $\begin{array}{c}0.058^{* * *} \\
(0.022)\end{array}$ & $\begin{array}{c}0.048^{* *} \\
(0.022)\end{array}$ & & & & $\begin{array}{c}0.005 \\
(0.028)\end{array}$ & $\begin{array}{c}0.024 \\
(0.027)\end{array}$ \\
\hline Access to food & & & & & $\begin{array}{c}-0.131 * * * \\
(0.020)\end{array}$ & & & & & $\begin{array}{c}-0.160^{* * *} \\
(0.023)\end{array}$ \\
\hline Access to water & & & & & $\begin{array}{c}-0.056^{* * *} \\
(0.020)\end{array}$ & & & & & $\begin{array}{l}-0.018 \\
(0.025)\end{array}$ \\
\hline Access to medical care & & & & & $\begin{array}{c}0.016 \\
(0.021)\end{array}$ & & & & & $\begin{array}{c}-0.053 * * \\
(0.023)\end{array}$ \\
\hline Access to cash income & & & & & $\begin{array}{c}0.026 \\
(0.024)\end{array}$ & & & & & $\begin{array}{l}-0.030 \\
(0.026)\end{array}$ \\
\hline Access to transportation & & & & & $\begin{array}{c}-0.075^{* * *} \\
(0.025)\end{array}$ & & & & & $\begin{array}{c}-0.097 * * * \\
(0.027)\end{array}$ \\
\hline Access to electricity & & & & & $\begin{array}{l}-0.040 \\
(0.025)\end{array}$ & & & & & $\begin{array}{l}-0.075^{*} \\
(0.041)\end{array}$ \\
\hline Constant & & & & & & $\begin{array}{c}0.940 * * * \\
(0.306)\end{array}$ & $\begin{array}{c}1.111 * * * \\
(0.309)\end{array}$ & $\begin{array}{c}1.533 * * * \\
(0.226)\end{array}$ & $\begin{array}{c}1.474 * * * \\
(0.230)\end{array}$ & $\begin{array}{c}1.757 * * * \\
(0.209)\end{array}$ \\
\hline First stage & & & & & & & & & & \\
\hline Rainfall growth & & & & & & $\begin{array}{c}0.035^{* * *} \\
(0.006)\end{array}$ & $\begin{array}{c}0.033^{* * *} * \\
(0.006)\end{array}$ & $\begin{array}{c}0.061 * * * \\
(0.008)\end{array}$ & $\begin{array}{c}0.057 * * * \\
(0.008)\end{array}$ & $\begin{array}{c}0.059^{* * * *} \\
(0.008)\end{array}$ \\
\hline Observations & 40,034 & 39,588 & 20,880 & 20,634 & 20,500 & 40,034 & 39,588 & 20,880 & 20,634 & 20,500 \\
\hline Log likelihood & -44831 & -44171 & -23413 & -23107 & -22882 & -32270 & -31597 & -15964 & -15696 & -15457 \\
\hline Wald chi2 & 5313 & 5408 & 3967 & 3954 & 4032 & 5641 & 5602 & 4399 & 4500 & 4940 \\
\hline Wald p-value & 0.00 & 0.00 & 0.00 & 0.00 & 0.00 & 0.00 & 0.00 & 0.00 & 0.00 & 0.00 \\
\hline Wald chi-squared test of exogeneity & & & & & & 4.30 & 3.31 & 6.68 & 6.55 & 9.25 \\
\hline Exogeneity test Wald p-value & & & & & & 0.04 & 0.07 & 0.01 & 0.01 & 0.00 \\
\hline Wald test of weak instrument & & & & & & $3.31 *$ & $2.97 *$ & $5.11 * *$ & $5.07 * *$ & $7.01 * * *$ \\
\hline Anderson-Rubin test of weak instrument & & & & & & $3.71^{*}$ & $2.84 *$ & $5.77 * *$ & $5.78^{* *}$ & $8.32 * * *$ \\
\hline
\end{tabular}


We control for the political affiliation of the respondent as well as some elections related matters in column (8). These variables include whether the respondent is a member of a political party, his/her interests in public affairs, his/her participation in the last election and judgment about the election: fairness of votes and participation of opposition parties, media coverage and the counting of votes. In fact, the outbreak of electoral violence is often related to the misjudgment of people on the election process. The exclusion of opposition parties can also spur electoral violence. We also control for the trust of the respondents in the national electoral commission, local government council, ruling party, police, army and courts of law. A lack of trust in the national election commission as well as the ruling party, and police and army can lead to protest and electoral violence, particularly when people do not trust the courts of law to reconsider some irregularities. Even controlling for these important covariates, we still find that the coefficient associated with our variable of interest-gender equality-is negative and significant at 1 percent level. The coefficient is higher than that of columns (6). Not surprisingly, we also find that respondents who reported that the election was fair and free, and the votes were counted fairly are less likely to be involved in electoral violence. Trust in election commission, ruling part and army are also associated with lower electoral violence, suggesting that more accountable, transparent and effective ruling party could help prevent electoral violence in Africa. On the contrary, those respondents who think that the opposition parties were prevented from participating in the election are more likely to report electoral violence.

Given the increasing role of media in election period and daily life, we control for the respondent's media channel in column (9). The media plays an important role during elections. The media act as a watchdog to ensure plurality of views, opinions, and transparent political processes, and offer a platform for candidates and voters to discuss important issues. However, the media can also amplify or even incite national prejudices or tensions during contentious elections. We control for the following media channel: radio, TV, newspapers and social media. Results in column (9) show that controlling for the media channel of respondents doesn't change our core results. The coefficient associated with gender equality remains negative and strongly significant at the 1 percent level. Furthermore, we also find that the coefficients associated with some media channels are positive and significant. This is 
line with Abdi and Jeane (2008) who found that the media had undermined democracy during the Kenya's post-election violence of 2008.

Finally, in column (10) we control for the access of the respondents to basic needs and assets including food, water, medical care, cash income, transportation and electricity. Poverty rate is very high in Africa, and this despair situation may lead to electoral violence as it has been shown in the literature that some politicians can exploit the impoverished conditions of the populations to mobilize and lead them to rebellion (Goodhand 2001). Poverty compounds vulnerability to insurgency at the individual and community level by lowering the opportunity cost of mobilizing for violence (Humphreys and Weinstein 2008). As can be seen in column (10) the impact of gender equality on electoral violence remains negative and significant at the 1 percent level. We also find that respondents who have never been without food medical care, transportation and electricity are less likely to report electoral violence.

\section{ROBUSTNESS CHECKS}

In this section we undertake a number of robustness checks.

\section{(i) Alternative definition of electoral violence}

In Table 3 we use an alternative definition of electoral violence where the respondents are asked whether electoral violence happen often in their countries (see section 3.A). We replicate the same regressions (columns 6-10) performed in Table 2. The results confirm our baseline findings according to which gender equality is negatively associated with electoral violence. 
Table 3: Robustness check: using alternative definition of electoral violence

\begin{tabular}{lccccc}
\hline VARIABLES & $(1)$ & $(2)$ & $(3)$ & $(4)$ & $(5)$ \\
\hline & & & & & \\
Gender equality & $-1.095^{*}$ & $-1.295^{*}$ & $-1.601^{* * *}$ & $-1.670^{* * *}$ & $-1.737^{* * *}$ \\
& $(0.656)$ & $(0.669)$ & $(0.482)$ & $(0.503)$ & $(0.477)$ \\
Constant & $1.132^{* * *}$ & $1.292^{* * *}$ & $1.693^{* * *}$ & $1.682^{* * *}$ & $1.840^{* * *}$ \\
& $(0.313)$ & $(0.300)$ & $(0.196)$ & $(0.198)$ & $(0.195)$ \\
First stage & & & & & \\
Rainfall growth & $0.036^{* * *}$ & $0.034^{* * *}$ & $0.062^{* * *}$ & $0.058^{* * *}$ & $0.059^{* * *}$ \\
& $(0.006)$ & $(0.006)$ & $(0.008)$ & $(0.008)$ & $(0.008)$ \\
Observations & 37,903 & 37,526 & 20,619 & 20,375 & 20,242 \\
Log likelihood & -31009 & -30476 & -15626 & -15370 & -15194 \\
Wald chi2 & 5241 & 5569 & 4965 & 5044 & 5162 \\
Wald p-value & 0.00 & 0.00 & 0.00 & 0.00 & 0.00 \\
Wald chi-squared test of exogeneity & 2.35 & 2.96 & 8.08 & 7.79 & 9.05 \\
Exogeneity test Wald p-value & 0.12 & 0.09 & 0.00 & 0.01 & 0.00 \\
Wald test of weak instrument & $2.75^{*}$ & $2.77^{*}$ & $6.81^{* * *}$ & $6.52^{* *}$ & $7.51^{* * *}$ \\
Anderson-Rubin test of weak instrument & $2.64^{*}$ & $3.04 *$ & $7.86^{* * *}$ & $7.62^{* * *}$ & $8.89^{* * *}$ \\
Control variables & Yes & Yes & Yes & Yes & Yes \\
\hline Standard errors in parentheses *** $\mathrm{p}<0.01, * * \mathrm{p}<0.05 * \mathrm{p}<0.1$ & & & \\
& &
\end{tabular}

\section{(ii) Alternative definition of gender equality}

Another important element of our analysis is the way in which we define gender equality. While we used female-to-male labor force participation ratio as an indicator of gender equality in our baseline regressions, there are several alternative definitions of gender equality indices that could have been used upon on data availability. The female-to-male labor force participation ratio is a relative measure of gender equality. We will use the female labor force participation rate, which is an absolute measure, as an alternative definition of gender equality to check the robustness of our baseline findings. Some previous studies have used this indicator (Caprioli 2000, 2005; Demeritt et al. 2014; Brussevich et al. 2018). Table 4 reports the results obtained using the female labor force participation rate as a measure of gender equality. As shown in Table 4, we find that the use of the alternative definition of gender equality delivers similar results. 
Table 4: Robustness check: using alternative definition of gender equality

\begin{tabular}{lccccc}
\hline VARIABLES & $(1)$ & $(2)$ & $(3)$ & $(4)$ & $(5)$ \\
\hline & & & & & \\
Gender equality & $-1.232^{* *}$ & $-1.260^{*}$ & $-2.319^{* * *}$ & $-2.463^{* * *}$ & $-2.820^{* * *}$ \\
& $(0.626)$ & $(0.733)$ & $(0.881)$ & $(0.925)$ & $(0.862)$ \\
Constant & $0.553^{* * *}$ & $0.763^{* * *}$ & $1.332^{* * *}$ & $1.278^{* * *}$ & $1.524^{* * *}$ \\
& $(0.149)$ & $(0.149)$ & $(0.170)$ & $(0.178)$ & $(0.166)$ \\
First stage & & & & & \\
Rainfall growth & $0.040^{* * *}$ & $0.034^{* * *}$ & $0.039^{* * *}$ & $0.036^{* * *}$ & $0.038^{* * *}$ \\
& $(0.002)$ & $(0.002)$ & $(0.004)$ & $(0.004)$ & $(0.004)$ \\
Observations & 40,216 & 39,768 & 20,974 & 20,728 & 20,594 \\
Log likelihood & -2172 & -507 & -707 & -658 & -501 \\
Wald chi2 & 4797 & 4896 & 3995 & 4062 & 4352 \\
Wald p-value & 0.00 & 0.00 & 0.00 & 0.00 & 0.00 \\
Wald chi-squared test of exogeneity & 3.69 & 2.91 & 5.61 & 5.68 & 8.11 \\
Exogeneity test Wald p-value & 0.05 & 0.09 & 0.02 & 0.02 & 0.00 \\
Wald test of weak instrument & $3.66^{*}$ & $2.80^{*}$ & $5.63 * *$ & $5.59^{* *}$ & $7.82^{* * *}$ \\
Anderson-Rubin test of weak instrument & $3.72^{*}$ & $2.85^{*}$ & $5.97 * *$ & $5.98^{* *}$ & $8.56^{* * *}$ \\
Control variables & Yes & Yes & Yes & Yes & Yes \\
\hline Stand
\end{tabular}

Standard errors in parentheses. ${ }^{* * *} \mathrm{p}<0.01,{ }^{* *} \mathrm{p}<0.05,{ }^{*} \mathrm{p}<0.1$

\section{(iii) Additional variables}

We also inquire robustness to the inclusion of more covariates. First, we include some indicators related to the respondents' perception of freedom in their country (see column 1, Table 5). In the sixth round of Afrobarometer surveys, respondents are asked whether or not they are free to join any political organizations or choose who to vote for. When voters feel that there is a lack of freedom, they may undertake public protest, and demonstrations to have their voice heard, which is more likely to happen around election time. The inclusion of the respondents' perception of freedom does not change our findings. The coefficient associated with gender equality is negative and strongly significant (column 1, Table 5).

Second, we control for the religious affiliations and fractionalization of respondents in column 2, Table 5. Some previous studies have found that religious fractionalization can spur on conflict (Montalvo and Reynal-Querol 2005) and that election related violence in Africa is fueled by religious divisions (Colombo et al. 2017; Eifert et al. 2010; Wilkinson 2004). We generate an index of religious fractionalization as in Montalvo and Reynal-Querol (2005). 
We find that even controlling for these important covariates the coefficient associated with gender equality is still negative and significant at the 1 percent level.

Third, we control for the respondents' perception of corruption in the country (see column 3, Table 5). Respondents are asked whether they think that there is corruption in the office of the President, members of Parliament, local government, police, judges, and traditional leaders. High perception of corruption can be a motive of demonstrations and rejection of election poll results, thereby leading to more electoral violence. Results including these corruption-related covariates are reported in column 3, Table 5. They are in line with our baseline findings.

Fourth, we include some variables related to the safeness in general in the respondents' surrounding living places (see column 4, Table 5). Wallsworth (2015) argued that it is important to incorporate what experience led a respondent to report a higher perceived level of violence. In Afrobarometer surveys, respondents are asked whether they feel unsafe walking in neighborhood, and whether they fear crime in home or have ever been physically attacked. We may suspect that the areas with high insecurity risks may be more likely to experience electoral violence. Results in column 4 show that our findings do not change after incorporating the respondents' perception of security risks in their living areas. 
Table 5: Robustness check: including additional variables

\begin{tabular}{|c|c|c|c|c|c|c|c|}
\hline VARIABLES & $(1)$ & $(2)$ & (3) & (4) & $(5)$ & $(6)$ & (7) \\
\hline Gender equality & $\begin{array}{c}-1.461 * * * \\
(0.513)\end{array}$ & $\begin{array}{c}-1.684 * * * \\
(0.467)\end{array}$ & $\begin{array}{c}-1.354 * * * \\
(0.436)\end{array}$ & $\begin{array}{c}-1.400 * * * \\
(0.513)\end{array}$ & $\begin{array}{c}-1.678 * * * \\
(0.480)\end{array}$ & $\begin{array}{c}-1.573 * * * \\
(0.462)\end{array}$ & $\begin{array}{c}-1.216^{* * * *} \\
(0.391)\end{array}$ \\
\hline Freedom of speech & $\begin{array}{c}-0.124 * * * \\
(0.028)\end{array}$ & & & & & & \\
\hline Freedom to join any political organizations & $\begin{array}{c}-0.096 * * * \\
(0.032)\end{array}$ & & & & & & \\
\hline Freedom to choose who to vote for & $\begin{array}{c}-0.069 * * \\
(0.028)\end{array}$ & & & & & & \\
\hline Member of religious group & & $\begin{array}{l}0.120 * * * \\
(0.021)\end{array}$ & & & & & \\
\hline Religious fractionalization & & $\begin{array}{c}0.082 \\
(0.064)\end{array}$ & & & & & \\
\hline Corruption in the office of the President & & & $\begin{array}{l}-0.036 \\
(0.043)\end{array}$ & & & & \\
\hline Corruption in the office of Parliament & & & $\begin{array}{c}0.004 \\
(0.054)\end{array}$ & & & & \\
\hline Corruption in the office of the government & & & $\begin{array}{c}0.044 \\
(0.062)\end{array}$ & & & & \\
\hline Corruption in the office of the local government & & & $\begin{array}{l}-0.082^{*} \\
(0.050)\end{array}$ & & & & \\
\hline Corruption in the police & & & $\begin{array}{c}0.021 \\
(0.053)\end{array}$ & & & & \\
\hline Corruption in the office of judges & & & $\begin{array}{l}-0.012 \\
(0.045)\end{array}$ & & & & \\
\hline Corruption by traditional leaders & & & $\begin{array}{l}0.190 * * * \\
(0.033)\end{array}$ & & & & \\
\hline Corruption by religious leaders & & & $\begin{array}{c}0.069 * * \\
(0.029)\end{array}$ & & & & \\
\hline Safe walking in neighbourhood & & & & $\begin{array}{c}-0.169 * * * \\
(0.025)\end{array}$ & & & \\
\hline Never feared crime in home & & & & $\begin{array}{c}-0.174 * * * \\
(0.027)\end{array}$ & & & \\
\hline Never Had something stolen from house & & & & $\begin{array}{l}-0.028 \\
(0.023)\end{array}$ & & & \\
\hline Never been physically attacked & & & & $\begin{array}{c}-0.096 * * * \\
(0.034)\end{array}$ & & & \\
\hline Distance to petroleum sites & & & & & $\begin{array}{c}-0.021^{* *} \\
(0.008)\end{array}$ & & \\
\hline Area size & & & & & & $\begin{array}{l}0.033^{*} \\
(0.020)\end{array}$ & \\
\hline Density of the population & & & & & & $\begin{array}{c}0.005 \\
(0.007)\end{array}$ & \\
\hline Polity2 & & & & & & & $\begin{array}{l}-0.082^{* *} \\
(0.036)\end{array}$ \\
\hline GDP growth volatility & & & & & & & $\begin{array}{c}0.062 * * * \\
(0.011)\end{array}$ \\
\hline Inflation & & & & & & & $\begin{array}{l}0.061 * * \\
(0.031)\end{array}$ \\
\hline Share of women in parliament & & & & & & & $\begin{array}{l}-0.007 \\
(0.004)\end{array}$ \\
\hline Gini index & & & & & & & $\begin{array}{c}0.045 * * * \\
(0.012)\end{array}$ \\
\hline Constant & $\begin{array}{c}1.689 * * * \\
(0.231)\end{array}$ & $\begin{array}{c}1.695 * * * \\
(0.203)\end{array}$ & $\begin{array}{c}1.469 * * * \\
(0.223)\end{array}$ & $\begin{array}{c}1.960 * * * \\
(0.229)\end{array}$ & $\begin{array}{c}1.940 * * * \\
(0.239)\end{array}$ & $\begin{array}{c}1.684 * * * \\
(0.198)\end{array}$ & $\begin{array}{l}-0.576 \\
(0.436)\end{array}$ \\
\hline First stage & & & & & & & \\
\hline Rainfall growth & $\begin{array}{c}0.061 * * * \\
(0.008)\end{array}$ & $\begin{array}{c}0.061 * * * \\
(0.008)\end{array}$ & $\begin{array}{c}0.078 * * * \\
(0.009)\end{array}$ & $\begin{array}{c}0.062 * * * \\
(0.008)\end{array}$ & $\begin{array}{c}0.059 * * * \\
(0.008)\end{array}$ & $\begin{array}{c}0.064 * * * \\
(0.008)\end{array}$ & $\begin{array}{c}0.094 * * * \\
(0.009)\end{array}$ \\
\hline Observations & 20,261 & 20,381 & 16,273 & 20,428 & 20,500 & 20,500 & 18,970 \\
\hline Log likelihood & -15216 & -15354 & -13161 & -15260 & -15449 & -15434 & -14751 \\
\hline Wald chi2 & 4663 & 4991 & 3884 & 4668 & 4973 & 4769 & 4207 \\
\hline Wald p-value & 0.00 & 0.00 & 0.00 & 0.00 & 0.00 & 0.00 & 0.00 \\
\hline Wald chi-squared test of exogeneity & 6.98 & 9.87 & 8.26 & 6.44 & 9.33 & 9.39 & 9.19 \\
\hline Exogeneity test Wald p-value & 0.01 & 0.00 & 0.00 & 0.01 & 0.00 & 0.00 & 0.00 \\
\hline Wald test of weak instrument & $5.4 * *$ & $7.5 * * *$ & $6.51 * *$ & $5.17 * *$ & $7.06 * * *$ & $7.21 * * *$ & $7.21 * * *$ \\
\hline Anderson-Rubin test of weak instrument & $6.14 * *$ & $8.95 * * *$ & $7.36 * * *$ & $5.79 * *$ & $8.41 * * *$ & $8.39 * * *$ & $7.91 * * *$ \\
\hline Control variables & Yes & Yes & Yes & Yes & Yes & Yes & Yes \\
\hline
\end{tabular}


Fifth, we control for the distance between the administrative region of the respondent and the closest petroleum site. Several studies have shown that oil extraction positively affects the occurrence of conflict in Africa (see Lei and Michaels, 2014). To control for the potential effects of petroleum activities, we use the distance to on-shore petroleum site, measured in meters and derived from PRIO global on-shore petroleum dataset (Ben Yishay et al 2017). As can be seen in column 5 of Table 5, our results remain intact even controlling for petroleum activities. Furthermore, the coefficient associated with the variable "Distance to petroleum sites" is negative and significant, suggesting that respondents who are living far from petroleum sites are less likely to report electoral violence.

Sixth, we control for the density and the size of respondents' administrative regions (see column 6, Table 5). Data are from the Center for International Earth Science Information Network. Our baseline results remain strongly robust. Furthermore, the largest administrative regions are more likely to experience electoral violence.

Finally, we control for some macroeconomic variables including GDP growth rate volatility, inflation rate, and the level of democracy in the country represented by the variable "Polity2" from the Polity IV Project database (Jaggers and Marshall, 2011). All the macroeconomic variables are from the IMF's World Economic Outlook (WEO). We also include two variables related to the level of income inequality in the country measured by the Gini index, and the share of women in the national parliament. Both the two variables are from the World Bank's World Development Indicators. We computed the average of these variables for the last 5 years (2010-2014) to avoid the simultaneity issue. In fact, violence can originate from difficult macroeconomic conditions and a deep lack of democratic values in the country. By controlling for the Gini index and the share of women in the national parliament, we make sure that the other forms of inequality in the country, namely the distribution of income and the political participation of women, are taken onboard. Results including these macroeconomic and political variables are reported in column 7 (Table 5). We observe that our findings are robust to the inclusion of these variables. The coefficient associated with gender equality remains negative and strongly significant at 1 percent level. We also observe that countries with high inflation rate, growth volatility and income inequality are more likely 
to experience electoral violence, while democratic nations are less likely to be subject to electoral violence.

\section{(iv) Excluding countries of the sample}

We perform a series of robustness checks by dropping the countries of the sample one by one. It is plausible that the impact of gender equality on election related violence is driven by some countries that have some specific characteristics that are not controlled for or perhaps they are either prone to electoral violence or where women dominate the labor market due to the natural demographic characteristics in the country. In Table 6, we make individual exclusions of countries of the sample and report the coefficients associated with our variable of interest-gender equality. It is worth noting that all control variables of Table 2, column 6 are included in the regressions. Results are reported in Table 6. We find that the coefficients associated with gender equality is negative and strongly significant in all columns. Thus, our findings are consistent regardless of the country excluded from the sample.

Table 6: Robustness check: exclusion of countries of the sample

\begin{tabular}{|c|c|c|c|c|c|c|c|c|c|c|c|c|}
\hline \multirow{3}{*}{$\begin{array}{l}\text { Country dropped } \\
\text { Burundi }\end{array}$} & \multirow{2}{*}{\multicolumn{2}{|c|}{ Gender equality }} & \multirow{2}{*}{\multicolumn{2}{|c|}{$\begin{array}{c}\text { First stage } \\
\text { Rainfall growth }\end{array}$}} & \multirow{3}{*}{$\begin{array}{c}\text { Observations } \\
19,821\end{array}$} & \multirow{3}{*}{$\begin{array}{c}\text { Log likelihood } \\
-14390\end{array}$} & \multirow{3}{*}{$\begin{array}{c}\text { Wald chi2 } \\
4714\end{array}$} & \multirow{3}{*}{$\begin{array}{c}\begin{array}{c}\text { Wald p- } \\
\text { value }\end{array} \\
0.00\end{array}$} & \multirow{3}{*}{$\begin{array}{r}\text { Wald chi-squared } \\
\text { test of exogeneity }\end{array}$} & \multirow{3}{*}{$\begin{array}{c}\begin{array}{c}\text { Exogeneity test } \\
\text { Wald p-value }\end{array} \\
0.00\end{array}$} & \multirow{3}{*}{$\begin{array}{c}\begin{array}{c}\text { Wald test } \\
\text { of weak } \\
\text { instrument }\end{array} \\
6.91^{* * *}\end{array}$} & \multirow{3}{*}{$\begin{array}{c}\begin{array}{c}\text { Anderson-Rubin } \\
\text { test of weak } \\
\text { instrument }\end{array} \\
8.21^{* * *}\end{array}$} \\
\hline & & & & & & & & & & & & \\
\hline & $-1.703^{* * *}$ & $(0.496)$ & $0.058^{* * *}$ & $(0.008)$ & & & & & & & & \\
\hline Benin & $-1.938^{* * *}$ & $(0.590)$ & $0.043^{* * *}$ & $(0.008)$ & 19,851 & -14708 & 5439 & 0.00 & 7.13 & 0.01 & $5.14^{* *}$ & $6.53^{* *}$ \\
\hline Burkina Faso & $-1.661 * * *$ & $(0.480)$ & $0.060 * * *$ & $(0.009)$ & 20,500 & -15457 & 4940 & 0.00 & 9.25 & 0.00 & $7.01 * * *$ & $8.32 * * *$ \\
\hline Cote d'Ivoire & $-1.712 * * *$ & $(0.469)$ & $0.060^{* * *}$ & $(0.009)$ & 19,727 & -14792 & 4762 & 0.00 & 10.14 & 0.00 & $7.54 * * *$ & $9.06^{* * *}$ \\
\hline Cameroon & $-1.736^{* * *}$ & $(0.470)$ & $0.059 * * *$ & $(0.009)$ & 19,908 & -15161 & 5067 & 0.00 & 9.97 & 0.00 & $7.48 * * *$ & $9.07 * * *$ \\
\hline Algeria & $-1.984 * * *$ & $(0.448)$ & $0.056^{* * *}$ & $(0.009)$ & 19,876 & -15216 & 5701 & 0.00 & 12.13 & 0.00 & $8.57^{* * *}$ & $11.23^{* * *}$ \\
\hline Gabon & $-1.774 * * *$ & $(0.427)$ & $0.065^{* * *}$ & $(0.009)$ & 19,977 & -15144 & 5115 & 0.00 & 12.38 & 0.00 & $9.23^{* * *}$ & $11.28 * * *$ \\
\hline Ghana & $-1.763 * * *$ & $(0.478)$ & $0.057 * * *$ & $(0.009)$ & 19,755 & -15182 & 5096 & 0.00 & 9.73 & 0.00 & $7.21 * * *$ & $8.84 * * *$ \\
\hline Guinea & $-1.695 * * *$ & $(0.500)$ & $0.057^{* * *}$ & $(0.008)$ & 19,930 & -14405 & 4791 & 0.00 & 9.31 & 0.00 & $6.74 * * *$ & $8.03^{* * *}$ \\
\hline Kenya & $-1.637 * * *$ & $(0.456)$ & $0.063^{* * *}$ & $(0.009)$ & 19,115 & -14951 & 4557 & 0.00 & 9.63 & 0.00 & $7.48^{* * *}$ & $8.88^{* * *}$ \\
\hline Liberia & $-1.716^{* * *}$ & $(0.496)$ & $0.058 * * *$ & $(0.008)$ & 20,164 & -14515 & 4866 & 0.00 & 9.28 & 0.00 & $7.02 * * *$ & $8.33^{* * *}$ \\
\hline Morocco & $-1.661 * * *$ & $(0.480)$ & $0.060^{* * *}$ & $(0.009)$ & 20,500 & -15457 & 4940 & 0.00 & 9.25 & 0.00 & $7.01^{* * *}$ & $8.32 * * *$ \\
\hline Madagascar & $-1.496^{* * *}$ & $(0.509)$ & $0.065^{* * *}$ & $(0.008)$ & 19,688 & -13641 & 4007 & 0.00 & 7.42 & 0.01 & $6.03^{* *}$ & $6.76^{* * *}$ \\
\hline Mali & $-2.335^{* * *}$ & $(0.503)$ & $0.041 * * *$ & $(0.008)$ & 19,701 & -14267 & 6629 & 0.00 & 10.59 & 0.00 & $7.07^{* * *}$ & $10.19^{* * *}$ \\
\hline Mozambique & $-1.654 * * *$ & $(0.539)$ & $0.055^{* * *}$ & $(0.008)$ & 19,731 & -14268 & 4630 & 0.00 & 7.46 & 0.01 & $5.75^{* *}$ & $6.73 * * *$ \\
\hline Mauritius & $-1.653 * * *$ & $(0.466)$ & $0.061^{* * *}$ & $(0.009)$ & 19,856 & -15268 & 4736 & 0.00 & 9.75 & 0.00 & $7.27^{* * *}$ & $8.68^{* * *}$ \\
\hline Malawi & $-1.490 * * *$ & $(0.464)$ & $0.065^{* * *}$ & $(0.009)$ & 19,160 & -14912 & 4611 & 0.00 & 8.48 & 0.00 & $6.56^{* *}$ & $7.57 * * *$ \\
\hline Namibia & $-2.261 * * *$ & $(0.546)$ & $0.039^{* * *}$ & $(0.009)$ & 19,830 & -15007 & 6652 & 0.00 & 8.59 & 0.00 & $5.54^{* *}$ & $8.08 * * *$ \\
\hline Niger & $-1.711 * * *$ & $(0.437)$ & $0.064 * * *$ & $(0.009)$ & 19,821 & -15330 & 4580 & 0.00 & 11.41 & 0.00 & $8.53^{* * *}$ & $10.31 * * *$ \\
\hline Nigeria & $-1.760 * * *$ & $(0.509)$ & $0.056^{* * *}$ & $(0.008)$ & 19,185 & -13311 & 4633 & 0.00 & 9.40 & 0.00 & $6.98^{* * *}$ & $8.31 * * *$ \\
\hline Senegal & $-1.661 * * *$ & $(0.480)$ & $0.060^{* * *}$ & $(0.009)$ & 20,500 & -15457 & 4940 & 0.00 & 9.25 & 0.00 & $8.32 * * *$ & $7.01 * * *$ \\
\hline Sudan & $-1.938 * * *$ & $(0.590)$ & $0.043^{* * *} *$ & $(0.008)$ & 19,851 & -14708 & 5439 & 0.00 & 7.13 & 0.01 & $5.14^{* *}$ & $6.53^{* *}$ \\
\hline Sierra Leone & $-1.657 * * *$ & $(0.476)$ & $0.060^{* * *}$ & $(0.009)$ & 20,200 & -15345 & 4930 & 0.00 & 9.34 & 0.00 & $7.07 * * *$ & $8.41^{* * *}$ \\
\hline Swaziland & $-1.661^{* * *}$ & $(0.480)$ & $0.060^{* * *}$ & $(0.009)$ & 20,500 & -15457 & 4940 & 0.00 & 9.25 & 0.00 & $7.01^{* * *}$ & $8.32 * * *$ \\
\hline Togo & $-1.646^{* * *}$ & $(0.490)$ & $0.059 * * *$ & $(0.009)$ & 20,094 & -15127 & 4862 & 0.00 & 8.72 & 0.00 & $6.69^{* * *}$ & $7.90^{* * *}$ \\
\hline Tunisia & $-1.683 * * *$ & $(0.435)$ & $0.067 * * *$ & $(0.009)$ & 19,892 & -15019 & 4924 & 0.00 & 11.42 & 0.00 & $8.57 * * *$ & $10.25^{* * * *}$ \\
\hline Tanzania & $-1.216^{* * *}$ & $(0.391)$ & $0.094 * * *$ & $(0.010)$ & 18,970 & -14751 & 4207 & 0.00 & 9.19 & 0.00 & $7.21 * * *$ & $7.91 * * *$ \\
\hline South Africa & $-1.757 * * *$ & $(0.417)$ & $0.069^{* * *}$ & $(0.009)$ & 19,095 & -14838 & 4973 & 0.00 & 12.50 & 0.00 & $9.34^{* * *}$ & $11.46^{* * *}$ \\
\hline Zambia & $-1.847 * * *$ & $(0.473)$ & $0.055^{* * *}$ & $(0.009)$ & 19,969 & -15081 & 5328 & 0.00 & 10.52 & 0.00 & $7.68^{* * *}$ & $9.58 * * *$ \\
\hline Zimbabwe & $-1.419 * * *$ & $(0.437)$ & $0.072 * * *$ & $(0.009)$ & 19,474 & -15016 & 4314 & 0.00 & 9.24 & 0.00 & $7.08 * * *$ & $8.04 * * *$ \\
\hline
\end{tabular}




\section{CONCLUSION}

This paper provides an empirical analysis of the impact of gender equality on electoral violence in Africa. We use micro-level data from the sixth wave of Afrobarometer surveys which allow us to explore in-depth the role of gender in election related violence. The sample covers 40808 individuals from 30 African countries. We find a strongly significant and negative correlation between gender equality and electoral violence in Africa. According to our estimates, an increase in female-to-male labor force participation ratio by 1 percent point is associated with a decline of election related violence by around 4.2 percent point. We perform numerous sensitivity tests and show that the results are robust to a variety of alternative specifications. Although we employ an instrumental variable approach, we recall that our results may not fully imply causation as shocks in rainfall may have alternative channels beyond the labor market.

Our findings can be interpreted that promoting gender equality and equal opportunity could help reduce the problem of recurrent electoral violence in Africa. With many conflicts and civil wars on the continent originating from electoral violence, the results of this paper underline an important way of fostering peace and boosting democracy. African countries should promote gender equality to support women's economic empowerment. Improving women's participation in the labor market should be a priority not only because of equity, but also for the positive economic impact as evidence shows (Ostry et al, 2018; IMF, 2018) and the potential to reduce fragility and bring peace. The quest for peace in Africa must involve fighting all form of inequality and discrimination against women. 


\section{REFERENCES}

Abdi, J., and Deane, J. (2008). The Kenyan 2007 elections and their aftermath: the role of media and communication. Policy Briefing No. 1. London: BBC World Service Trust.

Adler, F. (1975). Sisters in Crime: The Rise of the New Female Criminal. New York: McGraw-Hill.

Allen, C., T., Swan, S. C., and Raghavan, C. (2009). Gender Symmetry, Sexism, and Intimate Partner Violence. Journal of Interpersonal Violence, 24(11): 1816-1834.

Asal, V., Legault, R., Szekely, O., and Wilkenfeld, J. (2013). Gender ideologies and forms of contentious mobilization in the Middle East. Journal of Peace Research 50: 305-318.

Atwood, R. (2012). How the EU can support peaceful post-election transitions of power: lessons from Africa. Briefing Paper (European Union: Brussels, Belgium)

Bardall, G. (2011). Breaking the Mold: Understanding Gender and Electoral Violence. International Foundation for Electoral Systems .

Ben Yishay, A., Rotberg, R., Wells, J., Lv, Z., Goodman, S., Kovacevic, L., Runfola, D. (2017). Geocoding Afrobarometer Rounds 1 - 6: Methodology \& Data Quality. AidData. Available online at http://geo.aiddata.org.

Blattman, C. (2009). From Violence to Voting: War and Political Participation in Uganda. American Political Science Review 103 (02): 231-247.

Bloom, M. (2011). Bombshell: The many faces of women terrorists. Toronto: Penguin.

Brancati, D., and Snyder, J. L. (2012). Time to Kill: The Impact of Election Timing on Postconflict Stability. Journal of Conflict Resolution 57 (5): 822-853.

Bratton, M. (2008). Vote buying and violence in Nigeria election campains. Electoral studies 27 (4): 621-632

Brussevich, M., Dabla-Norris, E., Kamunge, C., Karnane, P., Khalid, S., and Kochhar, K. (2018). Gender, Technology, and the Future of Work. Staff Discussion Note 18/07 (Washington DC: International Monetary Fund)

Buchard, S. M. (2015). Electoral violence in Sub-Saharan Africa: causes and consequences, Boulder CO: Lynne Rienner Publishers.

Bunch, C., and Carrillo, R. (1998). Global Violence against Women: The Challenge to Human Rights and Development.' In World Security, edited by M. T. Klare and Y. Chandrani: 229-248. New York, NY: St. Martins Press. 
Caprioli, M. (2000). Gendered conflict. Journal of Peace Research 37(1): 53-68.

Caprioli, M. (2005). Primed for violence: The role of gender inequality in predicting internal conflict. International Studies Quarterly 49: 161-178.

Chesney-Lind, M. (1986). Women and Crime: The Female Offender. Signs: Journal of Women in Culture and Society, 12(1): 78-96.

Chesney-Lind, M. (2006). Patriarchy, Crime, and Justice: Feminist Criminology in an Era of Backlash. Feminist Criminology, 1(6): 6-26.

Collier, P., Hoeffler, A., and Rohner, D. (2008). Beyond Greed and Grievance: Feasibility and civil war. Oxford Economic Papers 61 (1): 1-27.

Collier, P. and Vicente, P. (2012). Violence, Bribery, and Fraud: the Political Economy of Elections in Sub-Saharan Africa. Public Choice 153 (1-2): 117-147.

Collier, P. and Vicente, P. (2013). Votes and Violence: Evidence from a Field Experiment in Nigeria. The Economic Journal 124: 327-355.

Colombo, A., D'Aoust, O., and Sterck, O. (2017). From rebellion to electoral violence: Evidence from Burundi. Forthcoming in Economic Development and Cultural Change

Conover, P. J., and Sapiro, V. (1993). Gender, feminist consciousness, and war. American Journal of Political Science 37: 1079-1099.

Demeritt, J. H. R., Nichols, A. D. and Kelly, E. G. (2014). Female Participation and Civil War Relapse. Civil Wars 16(3): 346-368.

Dercon, S. and Gutiérrez-Romero, R. (2012). Triggers and Characteristics of the 2007 Kenyan Electoral Violence. World Development 40 (4): 731-744.

Dupas, P. and Robinson, J. (2010). Coping with Political Instability: Micro Evidence from Kenya's 2007 Election Crisis. American Economic Review 100 (2), 120-124.

Dupas, P. and Robinson, J. (2012). The (hidden) costs of political instability: Evidence from Kenya's 2007 election crisis. Journal of Development Economics 99 (2):314-329.

Eifert, B., Miguel, E., Posner, D. (2010). Political Competition and Ethnic Identification in Africa. American Journal of Political Science 54 (2): 494-510.

FAO (2011). The role of women in agriculture. ESA Working Paper No. 11-02 
Farmer, P. (2010). Partner to the Poor: A Paul Farmer Reader, edited by Haun Saussy. Berkeley: University of California Press.

Felmlee, D. H. (1982). Women's Job Mobility Processes Within and Between Employers. American Sociological Review 47(1): 142-151

Fischer, J. (2002). Electoral Conflict and Violence: A Strategy for Study and Prevention. IFES White Paper, 1.

Forsberg, E. and Olsson, L. (2016). Gender inequality and internal conflict, in Oxford Research Encyclopedias of Politics. Oxford: Oxford University Press.

Fuller, S. (2008). Job Mobility and Wage Trajectories for Men and Women in the United States. American Sociological Review 73(1): 158-183

Galtung, J. (1969). Violence, peace and peace research. Journal of Peace Research 6: $167-91$.

Galtung, J. (1975). Peace: Research, Education, Action: Essays in Peace Research. Volume One. Bucuresti, Romania: CIPEXIM.

Georges-Abeyie, D. E. (1983). Women as terrorists. In L. Z. Freedman and Y. Alexander (Eds.), Perspectives on terrorism. Wilmington: Scholarly Resources.

Goldsmith, A. A. (2014). Electoral violence in Africa revisited. Terrorism and Political Violence 5:1-20.

Goldstein, J. S. (2001). War and gender. Cambridge, U.K.: Cambridge University Press.

Goldstein, J. S. (2001). War and Gender: How Gender Shapes the War System and Vice Versa. Cambridge: Cambridge UP

Goodhand, J. (2001). Violent conflict, poverty, and chronic poverty. CPRC Working Paper 6. London: Chronic Poverty Research Centre, ODI

Gutiérrez-Romero, R. (2014). An Inquiry into the Use of Illegal Electoral Practices and Effects of Political Violence and Vote-buying. Journal of Conflict Resolution 58(8): $1500-1527$.

Höglund, K. (2009). Electoral Violence in Conflict-Ridden Societies: Concepts, Causes, and Consequences. Terrorism and Political Violence 21(3): 412-427

Hsueh, S. and Tienda, M. (1996). Gender, Ethnicity, and Labor Force Instability. Social Science Research 25(1): 73-94. 
Hudson, V. M., and den Boer, A. (2002). A surplus of men, a deficit of peace: Security and sex ratios in Asia's largest states. International Security 26(4): 5-38.

Hudson, V. M., Caprioli, M., Ballif-Spanvill, B., McDermott, R., and Emmett, C. F. (20082009). The heart of the matter: The security of women and the security of states. International Security 33(3): 7-45.

Humphreys, M., and Weinstein, J. M. (2008). Who fights? The determinants of participation in civil war. American Journal of Political Science 52(2): 436-455

IMF. (2018). How to Operationalize Gender Issues in Country Work. International Monetary Fund, Washington DC.

Jayne, T., Yeboah, F. K., and Henry, C. (2017). The future of work in Africa agriculture: trends and drivers of change. Working Paper No. 25, International Labor Organization, Geneva

Klasen, S., and Pieters, J. (2015). What Explains the Stagnation of Female Labor Force Participation in Urban India. World Bank Economic Review 29: 1-30.

Klopp, J. and Kamungi, P. (2007). Violence and elections: will Kenya collapse? World Policy Journal 24(4): 11-18.

Lei, Y.-H., and Michaels, G. (2014). Do Giant Oil Field Discoveries Fuel Internal Armed Conflicts? Journal of Development Economics 110: 139-57.

Looze, J. (2017). Why Do(n't) they leave? Motherhood and women's job mobility. Social Science Research 65: 47-59.

Marshall, M.G. and Jaggers, K. (2011). Polity IV Project. Technical Report. Center for Systemic Peace URL http://www.systemicpeace.org/polity/polity4.htm.

Melander, E. (2005a). Gender equality and intrastate armed conflict. International Studies Quarterly 49: 695-714.

Melander, E. (2005b). Political gender equality and state human rights abuse. Journal of Peace Research 42: 149-166.

Melander, E. (2016). Gender and civil war. In D. T. Mason \& S. McLaughlin Mitchell (Eds.), What do we know about civil wars? Lanham, MD: Rowman \& Littlefield.

Midlarsky, M. I. (1999). The Evolution of Inequality: War, State Survival, and Democracy in Comparative Perspective. Stanford, CA: Stanford University Press. 
Miguel, E., Satyanath, S. and Sergenti, E. (2004). Economic Shocks and Civil Conflict: an Instrumental Variables Approach. Journal of Political Economy 112(4): 725-753.

Moen, E., Lennart, N., and Edin, K. (2016). Volatile and Violent Relationships Among Women Sentenced for Homicide in Sweden Between 1986 and 2005. Victims \& Offenders, 11(3): 373-391.

Montalvo, J. G. and Reynal-Querol, M. (2005). Ethnic polarization, potential conflict and civil war. The American Economic Review 95(3): 796-816

O’Mahoney, J. (2012). Embracing Essentialism: A Realist Critique of Resistance to Discursive Power, Organization 19(6): 723-41

Omotola, S. (2010). Explaining Electoral Violence in Africa's "New" Democracies. African Journal on Conflict Resolution 10 (3): 51-73.

Ortbals, C.D. and Poloni-Staudinger, L.M. (2018). Gender and Political Violence: Women Changing the Politics of Terrorism. Springer International Publishing. https://doi.org/10.1007/978-3-319-73628-0

Ostry, J.D., Alvarez, J., Espinoza, R., and Papageorgiou, C. (2018). Economic Gains from Gender Inclusion: New Mechanisms, New Evidence. IMF Staff Discussion Note SDN/18/06, Washington DC

Pateman, C. (1970). Participation and Democratic Theory. Cambridge, UK: Cambridge University Press.

Robinson, J., and Torvik, R. (2009). The Real Swing Voter's Curse. American Economic Review 99 (2): 310-315.

Ross, M. H. (2000). The Relevance of Culture for the Study of Political Psychology. In Political Psychology: Cultural and Crosscultural Foundations, edited by S. Renshon and J. Duckitt: 33-46. New York, NY: New York University Press.

Royalty, A. B. (1998). Job-to-Job and Job-to Nonemployment Turnover by Gender and Education Level. Journal of Labor Economics 16:392-443.

Sayer, A. (1997). Essentialism, Social Constructivism, and Beyond. The Sociological Review 45(3): 453-87

Smith, D. (2001). The Problem of Essentialism. In Inger Skjelsbaek and Dan Smith (eds) Gender, Peace, and Conflict (Sage Publications 2001)

Sterck, O. (2017). Fighting for votes. Theory and evidence on the causes of electoral violence. CSAE Working Paper WPS/2015-19-2, Oxford 
Stotsky, J. G., Shibuya, S., Kolovich, L. and Kebhaj, S. (2016). Trends in Gender Equality and Women's Advancement. IMF Working Paper Series WP/16/21.

Suberu, R. T. (2007). Nigeria's muddled elections. Journal of Democracy 18(4):95-110.

Tessler, M., and Warriner, I. (1997). Gender, feminism, and attitudes toward international conflict: Exploring relationships with survey data from the Middle East. World Politics 49: 250-281.

UNDP. (2009). Elections and Conflict Prevention: A Guide to Analysis, Planning and Programming. New York: UNDP.

UNESCO (1995). Statement on Women's Contribution to a Culture of Peace. Presented to the Fourth World Conference on Women, Beijing.

United States Geological Survey (USGS). (2014). Mineral Facilities of Africa and the Middle East. National Minerals Information Center.

Wallsworth, G. (2015). Electoral violence: comparing theory and reality. http://econ.msu.edu/seminars/docs/WallsworthElectionViolenceSept2014Draft.pdf

Wilkinson, S. (2004). Votes and Violence: Electoral Competition and Ethnic Riots in India. Cambridge University Press, Cambridge, UK.

Willmott, C. J. and Matsuura, K. (2001). Terrestrial Air Temperature and Precipitation: Monthly and Annual Time Series (1950 - 1999), http://climate.geog.udel.edu/ climate/html pages/README.ghen ts2.html.

Winter, D. D. N. and Leighton, D. C. (2001). "Structural Violence: Introduction": 99-101, in Peace, Conflict, and Violence: Peace Psychology for the 21st Century, edited by Daniel J. Christie, Richard V. Wagner, and Deborah Du Nann Winter. Upper Saddle River, NJ: Prentice Hall.

Wolfgang, M. and Ferracuti, F. (1967). The Subculture of Violence. London: Tavistock.

World Bank. (2013). Unlocking Africa's Agricultural Potential. World Bank: Washington 